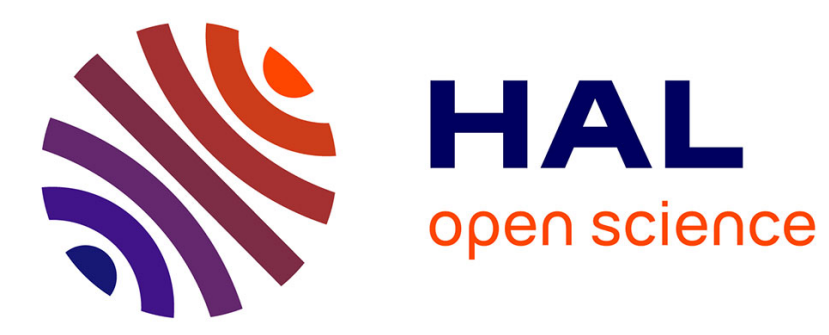

\title{
Denominal necessity modals in Basque
}

Ricardo Rikardo, R. Etxepare, Myriam Uribe-Etxebarria

\section{To cite this version:}

Ricardo Rikardo, R. Etxepare, Myriam Uribe-Etxebarria. Denominal necessity modals in Basque. Urtzi Etxeberria, Ricardo Etxepare and Myriam Uribe-Etxebarria. DPs and Nominalizations in Basque, John Benjamins, 2011. artxibo-00654937

\section{HAL Id: artxibo-00654937 https://artxiker.ccsd.cnrs.fr/artxibo-00654937}

Submitted on 23 Dec 2011

HAL is a multi-disciplinary open access archive for the deposit and dissemination of scientific research documents, whether they are published or not. The documents may come from teaching and research institutions in France or abroad, or from public or private research centers.
L'archive ouverte pluridisciplinaire HAL, est destinée au dépôt et à la diffusion de documents scientifiques de niveau recherche, publiés ou non, émanant des établissements d'enseignement et de recherche français ou étrangers, des laboratoires publics ou privés. 
Revised version to appear in

U. Etxeberria, R. Etxepare and M. Uribe-Etxebarria (eds)

DPs and Nominalizations in Basque. John Benjamins.

\author{
Denominal necessity modals in Basque ${ }^{1}$ \\ Ricardo Etxepare (CNRS-IKER) and Myriam Uribe-Etxebarria (EHU-UPV)
}

\begin{abstract}
Basque has a noun meaning need and a modal form, traditionally classified as verbal, homophonous to it, as in English. This paper provides a derivational account of the relation between the nominal and the so-called verbal need in Basque, by claiming that the purported verbal cases are derived from the nominal ones. This derivational relation, we argue, does not follow from the incorporation of Basque need into a verbal head, as has been recently claimed for English need. The necessity modal forms an independent clausal constituent with a DP or a non-finite clause representing the content of the need as its sole argument. This clausal constituent is merged to a high applicative head that introduces in the structure the experiencer of the need. The Basque modal construction resembles in this regard the nominal modal constructions found in some of the celtic languages such as Irish or Scottish Gaelic. This structure is merged with an intransitive verb $\mathrm{BE}$, which provides the verbal support for the construction. The incorporation of the applicative head to $\mathrm{BE}$ results in the transitive auxiliary have in Basque, a phenomenon that is independently attested outside the modal cases.
\end{abstract}

\title{
1. Introduction
}

This paper focuses on a subset of modal constructions in Basque: those involving the necessity modal behar ('need'/'must'/'have to'). Behar can take either a DP or an uninflected clause as its complement, as illustrated in $(1 \mathrm{a}, \mathrm{b}) \mathrm{:}^{2}$

(1) a. Liburu bat behar dut Book one need Aux(have) 'I need a book'

\section{b. Liburu bat erosi behar dut} book one buy need Aux(have) 'I need to/must buy a book'

In addition to the verb behar, Basque also has a homophonous noun behar, which can be translated as 'obligation' or 'need'. As any other regular noun, nominal behar can be modified by an adjective (2a), and be selected by a postposition ( $2 b$ ) or a determiner (2c). It can also select a genitive object, as occurs in typical binominal structures (2d). In this regard, the Basque pair behar $_{\text {noun-}}$ behar $_{\text {verb }}$ is highly reminiscent of the English pair need noun-need $_{\text {verb. }}$.

\footnotetext{
1 This research was partly funded by the Basque Government [Programs: (i) Research Groups (GIC07/144-IT-210-07); (ii) Development of Research Nets in Humanities 2009 (HM-2009-1-1); and (iii) Mobility Programs (MV-2008-2-18) to M.U-E] and by the Spanish Ministry of Science and Innovation (FFI2008-04786 and FFI2011-29218). It has also been funded by the Agence National de la Recherche (France), via the project TSABL (ANR-07-CORP-033).

${ }^{2}$ As discussed by Etxepare \& Uribe-Etxebarria (2009, 2010a,b,c) and Balza (2010b), there is a wide variety of modal constructions in Basque involving the modal behar. In this paper we focus on the type which is usually considered the standard one, that where behar follows its complement and selects for a transitive auxiliary and an ergative subject (see Ormazabal 1990a). See also op. cit.above for discussion of the full range of modal constructions with behar. See also Haddican and Tsoulas, this volume, and references therein for related discussion.
} 
Revised version to appear in

U. Etxeberria, R. Etxepare and M. Uribe-Etxebarria (eds)

DPs and Nominalizations in Basque. John Benjamins.

(2) a. Behar handia dut

Need big aux

'I have a big need' b. Beharrean naiz
need-D-post am
'I am in need'

\author{
c. Beharra \\ need-D \\ 'The need'
}

\section{d. Ez dut horr-en beharr-ik \\ neg aux that-gen need-partitive \\ 'I don't have any need of that'}

We propose that modal behar is a derived verb in the two cases illustrated in (1). In particular, we argue that both in the configuration involving [behar + DP] in (1a) as well as in that involving [behar + non-finite clause] in (1b), where behar behaves as a lexical verb meaning 'need/must/have to', this modal is derived from nominal behar (see Etxepare \& Uribe-Etxebarria 2010a; see also Uribe-Etxebarria 1989b and 1990, for an early version of this idea). Kayne \& Harves (2008), Harves (2008) and Kayne (2009) have recently argued that English need derives from an underlying structure with the nominal need as the complement of a light verb have (a verb expressing ordinary possession), as roughly represented in (3):

\section{(3) HAVE [need ...]}

These authors observe, following Isačenko (1974), that those languages that do not possess a possessive have also lack a transitive modal verb need. Assuming this typological correlation, they propose that modal need is derived via incorporation of nominal need to possessive have (Isačenko 1974 and Noonan 1993).

As shown in (4a), Basque also has a possessive have, which freely alternates with a lexical verb meaning "to possess" (the verb eduki) in the expression of possession:

(4) a. Jonek liburu bat du Jon-erg book one has 'Jon has a book' b. Jonek liburu bat dauka

Jon-erg book one possesses

'Jon has/possesses a book'

Given this correlation, it is tempting to extend an incorporation analysis $\grave{a}$ la Harves \& Kayne to this language. We depart however from the specific underlying structure and the ensuing derivation proposed by these authors for English need. We will show that the derived verb behar differs both from its English lexical counterpart need and from ordinary denominal Basque verbs in several important respects: (i) it cannot take the inflectional morphology that regular verbs take, (ii) it differs from its English transitive counterparts with respect to the arity operations it accepts, and (iii) in the nominal syntactic distribution of the modal item in both transitive and intransitive modal constructions. We argue that the modal noun behar is the nominal predicate of a small clause whose subject (either a DP or a non finite clause) is the content of the need, as represented in (5):

$$
\text { ...[Small Clause DP/non-finite clause behar] }
$$

This clausal constituent merges to an adpositional head that introduces an independent argument, external to the clause: what we informally call the experiencer of the need. The adpositional is the complement of an intransitive verb be that provides the verbal support for the construction: 
Revised version to appear in

U. Etxeberria, R. Etxepare and M. Uribe-Etxebarria (eds)

DPs and Nominalizations in Basque. John Benjamins.

(6) ...BE [pP Subject EXPeriencer of need $P\left[\right.$ SMall Clause $\left\{\begin{array}{l}\text { DP } \\ \text { non finite clause }\end{array}\right\}$ behar $\left.\left._{\text {NEed }}\right]\right]$

In (6), $\mathrm{P}$ incorporates to the copula $\mathrm{BE}$, giving rise to transitive have. The underlying structure of modal constructions is thus akin to the one proposed for auxiliary have by Kayne (1993).

Under the account advocated for by these authors, the incorporation of the nominal complement need to have liberates this nominal from any Case requirement. The verb have (or a functional projection associated with it) can thus assign accusative case to the complement of need, which surfaces with the case typically assigned to the complement: accusative Case. Under the hypothesis we defend here the Case properties displayed by this type of structures is explained in a different way. Since nominal behar is a predicate in (6) it is exempted from meeting any case requirements. Transitive have is thus available to check the Case features of a nominal other than behar (incorporation of need is therefore not required to explain how Case is assigned under our approach).

The paper is organized as follows: in Sections 2 and 3, we present the basic syntactic features underlying the constructions involving modal behar in Basque, including its Case and agreement properties, as well as the syntactic status of their complement. In Section 4 we review Kayne's (2009) analysis of the verbal/nominal need alternation in English, which takes verbal need to derive directly from the incorporation of the noun need to a light verb HAVE, and show it cannot be directly transposed into Basque. Section 5 develops our alternative, according to which the derived denominal modal construction has its source in an underlying small clause whose predicate is the bare noun behar "need" and whose subject is the content of the need. The full structure we propose for this structure is that given in (6) above.

We provide several arguments showing that modal behar is a verb derived from this underlying predicative structure. One concerns the behavior of modal behar under several arity operations, in the sense of Reinhart and Siloni (2005), and in particular with respect to reflexivization and reciprocalization (Section 5.2.) Additional evidence comes from the analysis of other intransitive modal constructions involving behar (Section 5.3.). We further motivate our analysis in Section 6, where we focus on the status of the transitive auxiliary edun ('have'). We show that there are other constructions, independent of the modal ones under analysis, which also involve a nominal predicate and the transitive auxiliary edun ('have'), and must be derived by the incorporation of an abstract preposition to a copula external to the small clause, exactly as we propose for the modal constructions. Section 7 offers a summary of the paper and concludes the discussion.

\section{The transitive modal verb behar}

The Basque modal behar behaves as an ordinary transitive verb in many respects, as illustrated in (7).

(7) (Ni-k) liburuhori behar dut. 
Revised version to appear in

U. Etxeberria, R. Etxepare and M. Uribe-Etxebarria (eds)

DPs and Nominalizations in Basque. John Benjamins.

(I-erg) book that- $\varnothing$ abs need $\operatorname{Aux}($ have)3p.sg.A-3.psg.E

'I need that book'

In (7), behar takes a subject and a nominal complement and co-occurs with a transitive auxiliary $d u t$ ('I have'). As is the case with regular transitive clauses, the subject of behar bears ergative case, and the object surfaces with absolutive case. Notice also that, as indicated in the glosses, the auxiliary verb must agree with all the arguments of the predicate (in this case with the ergative subject and the absolutive object). Thus, as soon as we change the subject and the object in (7), the auxiliary shows a different agreement pattern, as illustrated in (8) and (9).

(8) Zu-e-k liburuhoriek behar dituzue

You-pl-erg book those-abs need Aux(have)3p.plA-2p.pl.E

'You guys need those books'

(9) Zu-k ni behar nauzu

You-erg I-abs need Aux(have)1psgA-2psgE

'You need me'

Following the option available for DPs with structural case in Basque (see Duguine, 2011 and this volume), the arguments of behar can be null.

(10) a. Ni-k liburu horiek behar ditut

I-erg book those-abs need Aux(have)3p.pl.A-3p.sg.E

'I need those books'

b. - behar ditut
I-erg 3sP-abs need Aux(have)3p.pl.A-3p.sg.E
'I need them'

(11) a. Zu-k ni behar nauzu

you-erg I-abs need Aux(have)1psgA-2p.sg.E

'You need me'

b.
You-erg - I-abs need Aux(have)1psgA-2p.sg.E
'You need me'

Summarizing: from the point of view of Case and agreement, the constructions involving modal behar display all the features typically associated with transitive structures.

In addition to nominal objects, the transitive modal verb behar can also take uninflected verbal complements, as illustrated in (12) (see Balza, 2010b, Etxepare \& UribeEtxebarria 2009, 2010a,b,c and references therein).

\footnotetext{
Jone-k etorri behar $d u$

Jone-erg come-partc behar Aux(have)3p.sg.A-3p.sg.E

'Jone needs to/must/has to come'
} 
Revised version to appear in

U. Etxeberria, R. Etxepare and M. Uribe-Etxebarria (eds)

DPs and Nominalizations in Basque. John Benjamins.

Notice that in (12) behar behaves as a transitive modal verb: although the verbal complement of behar, the verb etorri ('to come'), is an unaccusative predicate, the auxiliary selected by behar is transitive. This auxiliary displays agreement with the matrix subject, which must bear ergative case (realized as $-k$ ). This is otherwise impossible in Basque: as shown in (13), unless behar is present, unaccusative verbs like etorri ('come') can never take transitive auxiliaries or ergative subjects.

$$
\begin{array}{ll}
* N i-k \text { etorri } & d u t \\
\text { I-erg come } & \text { Aux(have)3p.sg.A-3p.sg.E } \\
\text { 'I have come' } &
\end{array}
$$

Thus, we have to conclude that the configuration [non-finite verbal complement + behar] displays all the features of regular transitive structures: independently of whether the verb of the non-finite verbal complement is transitive or intransitive, the subject must surface with ergative case and the auxiliary must be transitive.

In the following section we summarize some of the most distinctive properties of the configuration [ non-finite verbal complement + behar], and define the type of noninflected complement that can cooccur with behar .

\section{Behar and non-finite complements}

\subsection{Obligatory agreement with the embedded arguments}

In (13), the verb of the non-finite complement of behar was unaccusative. But, in addition to non-finite intransitive complements, behar can also take non-finite transitive predicates, as shown in (14).

$$
\begin{aligned}
& \text { Ni-k liburua irakurri behar dut } \\
& \text { I-erg book-det-abs read need Aux(3p.sg.A-1p.sg.E) } \\
& \text { 'I need/must to read the book' }
\end{aligned}
$$

A distinctive property of this construction is that the main auxiliary necessarily agrees with all the arguments of the embedded non-finite predicate.

$$
\begin{aligned}
& (\mathrm{Zu-k}) \text { ipuin-ak irakurri behar zenituzke } \\
& \text { You-erg stories-det.pl.-abs read-ptc need Aux(have)3p.pl.A-2p.sg.E } \\
& \text { 'You would need to/would have to/should read books' }
\end{aligned}
$$

In (15) the auxiliary verb zenituzke shows agreement both with the ergative subject (zuk, 'you') and with the absolutive DP ipuinak ('stories'), the complement of irakurri 'to read'. If we add another argument in the non-finite verbal complement, the main auxiliary also has to agree with it. This is illustrated in (16a-c). In (16a) we have introduced a dative argument in the non-finite complement of behar, the DP Elenari 'to Elena', and the auxiliary must agree with it. If the auxiliary fails to agree with any of the embedded arguments, as in the case of (16b) and (16c), the result is ungrammatical.

$$
\text { a. }(Z u-k) \quad \text { Elena-ri ipuin-ak irakurribehar zenizkioke }
$$


Revised version to appear in

U. Etxeberria, R. Etxepare and M. Uribe-Etxebarria (eds)

DPs and Nominalizations in Basque. John Benjamins.

You-erg Elena-dat stories-det.pl.-abs read-ptc need Aux(have)3plA-3sgD-2sg.E

'You would need to/would have to/should read stories to Elena'

b. * (Zu-k) Elena-ri ipuin-ak irakurri behar zenioke

You-erg Elena-dat stories-det.pl.-abs read-ptc need Aux(have)3sgA-3sgD-2sg.E

'You would need to/would have to/should read books like these to Elena'

( $\rightarrow$ no number agreement with the 3 p.plural absolutive)

c. * $(Z u-k)$ Elena-ri ipuin-ak irakurri behar zenituzke

You-erg Elena-dat book-det.pl.-abs read-ptc need Aux(have)3p.plA-2p.sg.E

'You would need to/would have to/should read books like these to Elena'

$(\rightarrow$ no agreement with the dative argument)

(16b) is bad because the main auxiliary fails to agree in number with the embedded object (the form zenioke shows singular agreement with the embedded object ipuinak, which is plural and not singular). (16c) is illformed because the form zenituzke does not show agreement with the embedded 3 p.sg. dative DP Elenari 'to Elena'.

\subsection{The interpretation of the embedded subject}

One property of the type of construction illustrated in (12) or (14-16a), where behar takes a non-finite complement, is that the embedded subject is obligatorily controlled. If the subject is not controlled, the embedded non-finite verb must surface with a different morphology: it must take the suffix -tzea (See Duguine, this volume, and San Martin, this volume, for related discussion). This requirement is illustrated in (17-18):

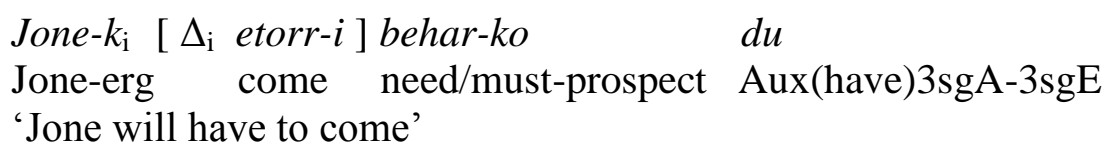

Jone- $k_{\mathrm{i}} \quad\left[\left(z u_{\mathrm{j}} / \Delta_{\mathrm{k}}\right)\right.$ etor-tze- $\left.a\right]$ beharko $d u$ Jone-erg $_{\mathrm{i}}\left(\right.$ you $\left._{\mathrm{j}} / \Delta_{\mathrm{k}}\right)$ come-tze-D behar-prosp Aux(have)3sgA-3sgE 'Jone ${ }_{\mathrm{i}}$ will need that you $/ \Delta_{\mathrm{k}}$ come'

Summarizing, the construction involving modal behar behaves as a transitive structure, both when behar takes a DP or a non-inflected verbal complement: the subject surfaces with ergative Case and the auxiliary is transitive. Further, in addition to agreement with the subject, the transitive auxiliary must also agree with the complement (when this is a DP) or with all the arguments of the embedded verb (when the complement is a noninflected clause). Finally, when the complement is a non-finite clause, this modal construction is an Obligatory Control structure (the embedded subject is interpreted as being obligatorily controlled by the matrix subject).

We have seen that behar can take a non-inflected clause as its complement. But, what is the size of this embedded complement? We address this question in the next sections.

\subsection{Lack of aspectual modification}


Revised version to appear in

U. Etxeberria, R. Etxepare and M. Uribe-Etxebarria (eds)

DPs and Nominalizations in Basque. John Benjamins.

In the previous sections we have shown that the complement of behar can be a VP, when the embedded non-inflected complement is intransitive (unacussative), as in (19a), and we have also shown that it can be a vP, since the embedded non-finite predicate can be transitive, as in (19b).

(19) a. Subjerg $\left[\mathrm{VP} \varnothing_{\text {Controlled subj }} \mathrm{V}_{\text {Intransitive }}\right.$ ]

BEHAR Aux TRANSITIVE

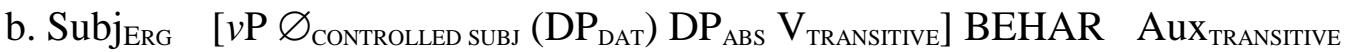

Let us now consider whether it can be bigger than than. We will start by analyzing whether the uninflected verbal complement of behar allows aspectual modification (that is, whether it can be an AspP). Consider the example in (20).

(20)
pro etorri izan behar
$d u$
s/he come have must/need
AuxTR-3p.sg.Erg.

In (20) the verb izan ('to be'/'to have') $)^{3}$ functions as an aspectual verb, and can be (roughly) translated as perfect have. If we followed the traditional analysis of Basque as a head final language, the phrase structure that corresponds to (20) would be that in $(21)^{4}$

TP

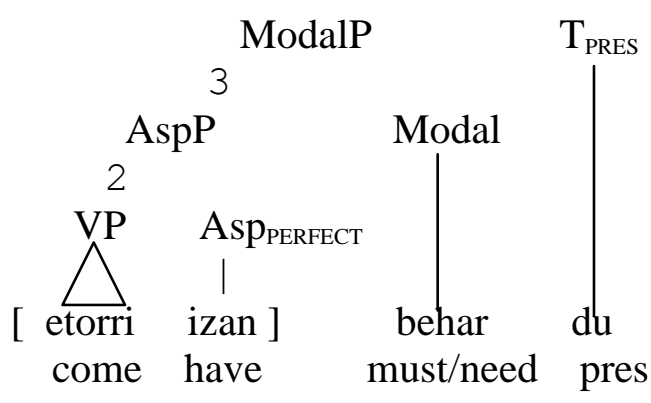

Under this analysis, (20) would be the Basque counterpart (the mirror image) of the English (22a) or the Spanish (22b). Note that in these examples, the modal takes scope over the aspectual verb (have/haber), just like behar takes scope over the perfect izan in (21).

\section{(22) a. She [ModP must [ASPP have [vP come ]] ] [ modal $>$ have $\mathrm{PERF}_{\mathrm{PEF}}$ ]}

b. Ella [ModP debe [AsPP haber [vP venido]] ] [ modal $>$ haber $_{\mathrm{PERF}}$ ]

However, the interpretation of (20) does not correspond to the interpretation of the examples in (22): while the examples in (22) have an epistemic interpretation, (20) does not license the epistemic reading and only allows a root construal -contrary to what follows from the structure in (21), the Perfect does not operate on the verb come, but

\footnotetext{
${ }^{3}$ Basque has no distinct infinitival form for the intransitive and transitive auxiliaries, which show different roots in their finite forms. Both have the same non-finite form, which is also their citation form: izan.

${ }^{4}$ Whether Basque is really a head final language or not is still subject to debate. The reader is referred to Arteatx, Artiagoitia \& Elordieta (eds.) (2008), and references therein, for extensive discussion on the head parameter in Basque.
} 
Revised version to appear in

U. Etxeberria, R. Etxepare and M. Uribe-Etxebarria (eds)

DPs and Nominalizations in Basque. John Benjamins.

rather on the modal behar. Further, speakers only accept (20) as a variant of the root modal construction in (23), where the aspectual head izan follows, instead of preceeding, the modal behar.

(23) Etorri behar izan du

Come need/must have Aux

'(S)he has had to come/(s)he needed to come'

We thus conclude that, despite appearences to the contrary, in (20) behar does not take an AspP as its complement. In other words, in (20) Asp must be hierarchically higher than the modal, as it constrains the interpretation of the modal (behar), and not the interpretation of the complement of the modal (etorri 'to come'). ${ }^{5}$

The conclusion that modal behar cannot take AspP as its complement is further confirmed when we turn to aspectual heads other than the perfect. Consider the examples in (24).

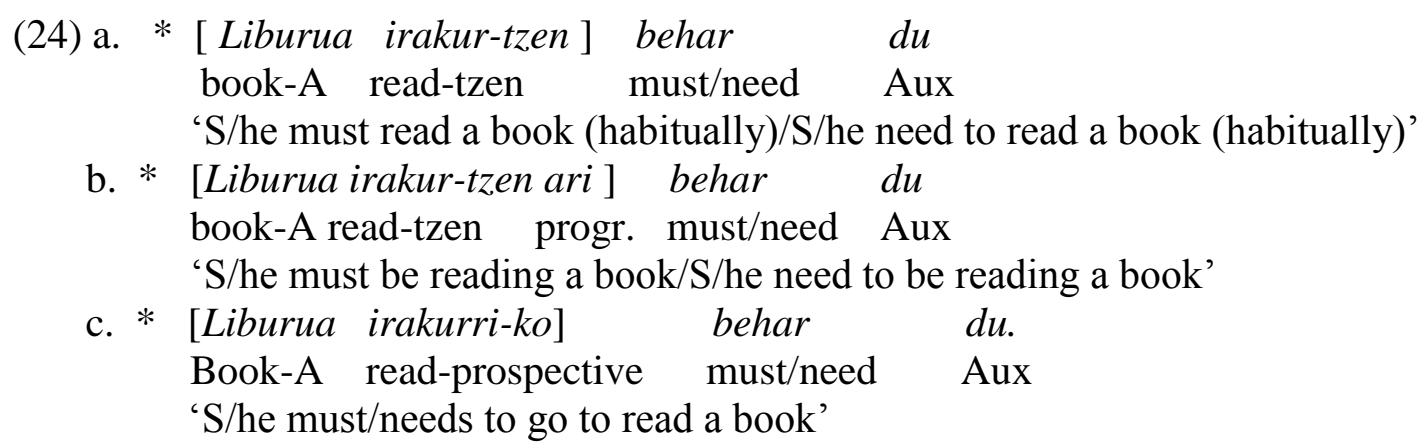

In (24a) we have attached different aspectual affixes to the complement of the modal, the verb irakurri ('to read'). In (24a) we have suffixed the morpheme-tzen, which is an aspectual marker used in continuative and habitual constructions. In (24b) we have added the complex aspectual marker -tzen ari, used to express progressive aspect. Finally, in (24c) we have the aspectual head $-k o$, used to express prospective aspect, attached to irakurri. As the grammaticality judgments indicate, all these constructions are ungrammatical: modal behar cannot take aspectually inflected complements. ${ }^{6}$ Note that this possibility is not ruled out in other languages, as shown by the examples in

\footnotetext{
${ }^{5}$ For detailed discussion on how to derive the different lineal orders of modal constructions involving aspectual verbs in Basque under a head final or head initial approach to Basque, see Haddican (2008) and Balza (2010a). See also Demirdache \& Uribe-Etxebarria (2009) for the interface between the morphosyntax of Basque modals and the differente modal construals they can give rise to.

${ }^{6}$ The only exception are cases like (i). In (i) the complement of behar licenses a progressive reading: (s)he must be reading a/the book".

(i) Liburua irakurtzen egon behar du

Book reading be must Aux

But notice that (i) is not an exception to the generalization we have given in the text. The reason why (i) is good is because egon is a lexical verb which, as its Spanish lexical counterpart estar, can give rise to a progressive construal. In other words, even if the complement of behar has a progressive reading in (i), the head of the complement of behar is not an aspectual morpheme (a functional head), but rather the lexical verb egon; thus, behar selects a VP, and not an AspP, in (i).
} 
Revised version to appear in

U. Etxeberria, R. Etxepare and M. Uribe-Etxebarria (eds)

DPs and Nominalizations in Basque. John Benjamins.

(25), where the modals deber (Sp. 'must'/'have to') and must take progressive, perfect, and even perfect progressive complements: ${ }^{7}$

(25) a. Ella debe haber leído el libro

a'. She must have read the book

b. Ella debe estar leyendo el libro

b'. She must be reading the book

c. Ella debe haber estado leyendo el libro

c'. She must have been reading the book

Summarizing, in contrast with modal verbs in other languages, transitive modal behar cannot subcategorize for an AspP in Basque.

\subsection{Temporal modifiers}

Further evidence that the non-inflected complement of the modal has a reduced size comes from the study of temporal adverbials: non-finite constructions preceding the modal do not admit any temporal modifier, as illustrated below. In (26a) the adverb atzo ('yesterday') modifies behar: the need is thus located in the temporal spam that corresponds to yesterday. As soon as we add a temporal modifier in the embedded complement, the sentence becomes ungrammatical, as shown in (26b), where we have introduced the adverb gaur ('today'). ${ }^{8}$

(26) a. Jon-ek atzo etxean egon behar zuen Jon-erg yesterday home-loc be need Aux [3p.sg.A-3p.sg.E] 'Jon needed to be at home yesterday"

$$
\begin{aligned}
& \text { b.* Jon-ek atzo gaur etxean egon behar zuen } \\
& \text { Jon-erg yesterday today home-loc be need Aux[3p.sg.A-3p.sg.E] } \\
& \text { 'Yesterday Jon needed to be at home today" }
\end{aligned}
$$

Since, as we have seen in the previous section, modal behar cannot take AspP as its complement, we interpret the impossibility to license independent temporal adverbials in the non-inflected complement as an indication that this complement cannot be a TP either.

\subsection{Negation}

7 The examples in (25), with present tense, only license an epistemic reading. However, modal constructions inflected for the past frecuently allow other modal readings. See Condoravdi (2002), Laca (2005, 2008) Borgonovo \& Cummins (2007) and references therein for related discussion. See also Demirdache \& Uribe-Etxebarria (2008a, b, 2010) for an approach that derives the different modal readings allowed by past modal constructions from a single phrase structure, without appealing to dedicated functional projections.

${ }^{8}$ One could argue that the ungrammaticality of (26b) is based on a semantic restriction: the impossibility of licensing the two adverbials yesterday and today in the same sentence. However, as shown by Etxepare \& Uribe-Etxebarria (2009), the constraint must be syntactic, as the double adverbial modification is possible when the embedded non-finite clause surfaces following, instead of preceeding, the modal. See Haddican \& Tsoulas (this volume) for related discussion. 
Revised version to appear in

U. Etxeberria, R. Etxepare and M. Uribe-Etxebarria (eds)

DPs and Nominalizations in Basque. John Benjamins.

Another property of the construction under analysis is that it does not license negation in the embedded complement. Thus, while a negative embedded complement is possible in other languages, as illustrated by the Spanish and English modal sentences in (27), its Basque counterparts in (28) are totally ungrammatical (no matter what the position of $e z$ (Neg) in the embedded complement is).

$\begin{aligned} & \text { Debes no } \\ & \text { must-you Nedarte en }\end{aligned}$ stay-CL casa tanto tiempo
'You must not stay at home for such a long time'

b. You must not stay at home alone

$$
\begin{aligned}
& \text { a. * Zu-k [etxea-n ez geratu] behar duzu } \\
& \text { You-erg home-loc Neg stay need Aux[3p.sg.A-2p.sg.E] } \\
& \text { 'You must not stay at home' } \\
& \text { b. * Zu- } k \text { [ez etxea-n geratu] behar duzu } \\
& \text { You-erg neg home-loc stay need Aux[3p.sg.A-2p.sg.E] } \\
& \text { 'You must not stay at home' } \\
& \text { c. * Zu- } k \text { [ etxea- } n \text { geratu ez ] behar duzu } \\
& \text { You-erg home-loc stay neg need Aux[3p.sg.A-2p.sg.E] } \\
& \text { 'You must not stay at home' }
\end{aligned}
$$

We thus conclude that the complement of behar cannot be a NegP either. This is not a surprising fact, considering the conclusions we have reached in the previous section. If, as Laka (1990) has defended, NegP is hierarchically higher than TP (Neg selects for TP in Basque), the fact that this type of modal construction does not seem to be able to take TP complements correlates with the fact that it cannot take NegP complements either. ${ }^{9}$

Summarizing the discussion so far: the complement of transitive behar can be either a DP or a non-finite clause (not larger than a vP).

Recall that at the beginning of this section we have shown that the matrix auxiliary has to display agreement with all the arguments of the embedded predicate. If this is correct, it suggests that, in contrast with other non-finite constructions, the embedded arguments cannot check their Case and agreement features within the non-finite clause and must look at the matrix domain to do it (See Duguine 2011 for related discussion).

\section{Alternative approaches to modal behar}

\subsection{Modal behar as an incorporated noun}

\footnotetext{
9 This is again another difference that distinguishes modal constructions where the non-inflected complement precedes behar from those ones where it follows this modal. While, as shown in the text, Negation is not licensed when the complement precedes behar, it is licensed when this complement follows behar. See Etxepare \& Uribe-Etxebarria (2009, 2010a,b,c) for detailed discussion of these facts. The reader is referred to Haddican \& Tsoulas (this volume) for related discussion.
} 
Revised version to appear in

U. Etxeberria, R. Etxepare and M. Uribe-Etxebarria (eds)

DPs and Nominalizations in Basque. John Benjamins.

Harves and Kayne have recently argued that the English modal verb need derives from an underlying structure where a nominal need is the complement of a transitive light verb have (a verb expressing ordinary possession) (Harves 2008, Harves \& Kayne 2008, Kayne 2009), as very roughly represented in (29=3):

(29) have [NP need ]

Assuming this structure, they propose that modal need is derived via incorporation of nominal need to the light verb (see also Uribe-Etxebarria 1989b, 1990 for related discussion). For ease of exposition, we could represent it schematically as in (30). ${ }^{10}$

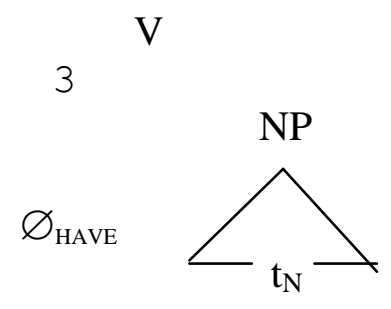

need

This analysis is based on the observation that transitive need implies the presence in the languages of transitive have (see Isačenko 1974 and Noonan 1993, Bhatt 1998).

Notice that although need remains a noun after incorporation to the empty verb have, the fact that it incorporates to this verbal head explains why it shows up "disguised" as a verb. On the one hand, "incorporation of the nominal need into the verbal head have results in the appearance of a transitive verb need inheriting the accusative Case licensing properties of have" (Kayne op.cit.: 4). Since the incorporated noun need does not need Case, have can assign Case to the complement of need, eliminating the need for the preposition of. Thus, if we start with a structure like (31), the incorporation of need into have would explain why in (32) need behaves as a transitive verb and why the object of need, the DP a new car, surfaces as the object of the transitive modal construction and receives accusative Case.

(31) They have $[$ need of a new car $]>$ they $[\text { need }+\varnothing \text { have }]_{\mathrm{V}}[\text { a new car }]_{\mathrm{ACC}}$

(32) They need a new car

In the absence of incorporation, need itself requires Case, either from have or from a $P$.

\section{(33) a. ? They have need of a new car}

b. They are in need of a new car Kayne (2009)

Summarizing, under Harves \& Kayne's analysis need is, strictly speaking, never a verb (it is a noun). But, although need is not a verb, for the reasons we have just discussed it surfaces as if it was one from the point of view of theta-role assignment and Case. Further, its incorporation into the empty head have also explains why it surfaces with verbal inflectional morphology, just as as any other verb in English.

\footnotetext{
${ }^{10}$ For ease of exposition, we represent the copies left by movement as traces.
} 
Revised version to appear in

U. Etxeberria, R. Etxepare and M. Uribe-Etxebarria (eds)

DPs and Nominalizations in Basque. John Benjamins.

(34) a. There will need to be more work done

b. He has always needed a sister

c. Despite needing a sister

d. They don't need to stay

e. They haven't needed to talk to us

f. They couldn't possibly have needed to do that

(Kayne 2009)

The incorporation analysis proposed by Harves \& Kayne captures the generalization that only languages that have a possessive auxiliary-like have possess also a transitive need and explains in a simple and an elegant way the verbal behavior and the inflectional properties of the denominal modal need.

4.2. Problems for an incorporation analysis of the modal in Basque: the inflectional morphology of behar

Just like English, Basque also has an auxiliary-like transitive have in possessive constructions, as shown in (4a) above and in (35) below.

(35) Zu-k liburu asko dituzu

You-Erg book many-Abs Aux(have)3psgErg-3ps.pl.Abs

'You have many books'

Basque also has the counterparts of the two English structures in (31-32):

(36) a. Nik [horr-en beharr-a]dut

I-Erg [that-genit need-det] Aux(have)3psgA-1psgErg

'I have (the) need of that'

b. Ni [horr-en beharr-ean] nago

I-Abs [that-genit need-locative] am

'I am in (the) need of that'

Further, it also has a modal need that behaves as a transitive verb, taking either NP/DP complements or $\mathrm{vp} / \mathrm{VP}$ dependents. In this regard, it is tempting to extend an incorporation analysis à la Harves \& Kayne to this language.

We depart however from the derivation proposed by these authors for English need. As shown above, English need surfaces in all respects with the appearance of a regular verb. However this is not the case of Basque behar. While, as shown at length above, it is true that it behaves as a regular transitive verb, modal behar shows a sharp difference with regard to the inflectional paradigm displayed by ordinary verbs in Basque.

The first difference between this modal and other regular verbs is that in contrast with the majority of verbs in Basque - which take a special type of suffix $(-t u,-n, i)$ in their citation form (what is traditionally called 'the participial form)-, behar bears no suffix whatsoever. ${ }^{11}$ This is illustrated in (37).

\footnotetext{
${ }^{11}$ See Haddican \& Tsoulas (this volume) and references therein for related discussion on the so called participial/citation forms in Basque.
} 
Revised version to appear in

U. Etxeberria, R. Etxepare and M. Uribe-Etxebarria (eds)

DPs and Nominalizations in Basque. John Benjamins.

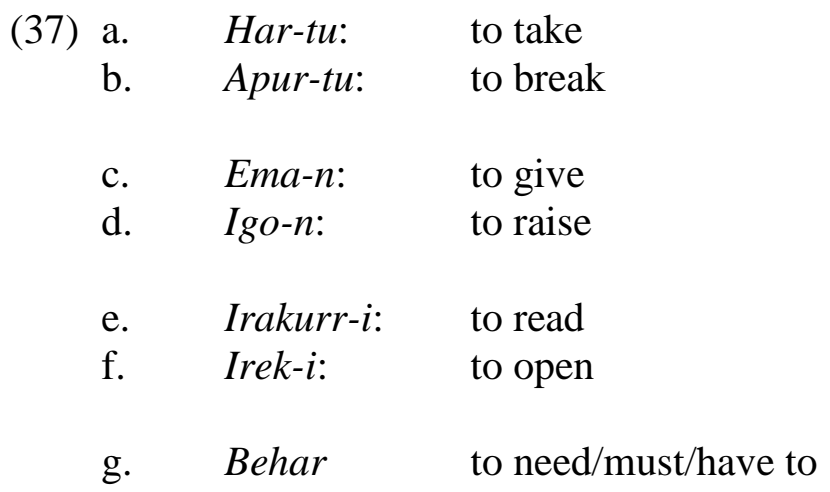

A second intriguing feature that distinguishes behar from regular verbs in Basque is that the purported verb behar does not possess non-finite forms. In this, the modal verb behar differs from denominal verbs derived from noun incorporation, such as dantzatu 'to dance' and borrokatu 'to fight', resulting from the incorporation of the independently existing nouns dantza 'dance' and borroka 'fight'. As shown by UribeEtxebarria (1989a), the latter have their source in complex predicate constructions involving a phonologically silent light verb (we will call it DO) and a bare noun. Their underlying structure is overtly manifested in their analytic counterparts dantza egin (lit. 'do dance') 'to dance', and borroka egin (lit. 'do fight') 'to fight', unergative verbs of activity (see Hale and Kayser, 1993, Rodríguez \& García Murga 2001, Gallego \& Irurtzun 2010, Odria \& Berro 2011 for related discussion)

$\begin{array}{cc}\begin{array}{c}\text { a. }[\mathrm{vp}[\mathrm{N} \text { Dantza }] \text { egin }] \\ \text { dance do }\end{array} & \text { b. [v Dantza-tu [N }(\text { dantza })]] \\ \text { dance } \\ \text { 'To dance' } & \text { 'To dance' }\end{array}$

Both the light verb egin "do" (39) and the denominal verb dantzatu "dance" (40) have infinitival $(39 a, 40 a)$, nominalized $(39 b, 40 b)$ and stem $(39 c, 40 c)$ forms :

\section{a. Dantza egin \\ Dance do+Ø \\ 'To dance'}

(40)

a. Dantzatu
dance-partc
'To dance'
b. Dantza egite dance do-nom 'Dancing'
b. Dantzatze
dance-nom
'Dancing'

c. Dantza egin dezan dance do Aux-subjunc 'So that (s)he may dance'
c. Dantza dezan dance Aux-subjunc 'So that (s)he may dance'

Behar, however, admits none of those forms: ${ }^{12}$
b. *Behartze need-nom

\author{
c. *Behar dezagun \\ need Aux-subj
}

\footnotetext{
${ }^{12}$ It should be pointed out that the form behartu, which we rule out as a possible form of behar in (41a), exists in Basque with the meaning of 'to force somebody to do something'. The foms in (41b) and (41c), considered to be impossible as uninflected forms of behar, are licensed as part of the verbal paradigm of behartu. What is important for us, however, is that even if these forms exist, they lack the modal reading that behar displays in Basque, so we analyze those forms as belonging to a different predicate, the verb behartu, and not to modal behar under analysis in this paper. We leave the question of how the verb behartu is derived for further research.
} 
Revised version to appear in

U. Etxeberria, R. Etxepare and M. Uribe-Etxebarria (eds)

DPs and Nominalizations in Basque. John Benjamins.

'To need' 'Needing' 'So that (s)he may need'

We thus contend that the necessity modal behar is related to its nominal base in a way other than ordinary syntactic incorporation.

Finally, there is another property of behar, related to the one we have just discussed, which separates behar from the rest of the verbal paradigm, and which has to do with the attachement of aspectual inflexional suffixes. While aspectual morphemes usually attach directly to the verbs in Basque (see (42)), the modal verb behar does not take any aspectual markers (except for the suffix of prospective aspect $-k o$ ), ${ }^{13}$ rather the aspectual morphemes must attach to a dummy auxiliary izan 'be/have'.

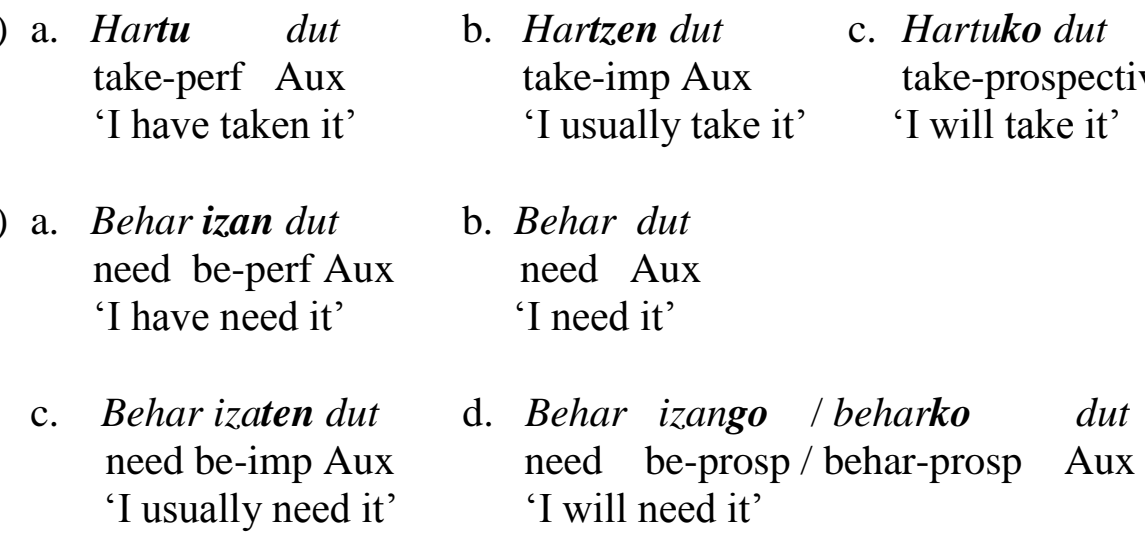

This is an unexpected result if, as proposed for English need, the Basque noun behar also incorporated into a silent counterpart of have. All these properties lead us to reject an incorporation analysis of modal behar, and look for an alternative explanation which derives the correlation between the existence of a transitive verb have and the existence of transitive modals in a different way. Before we move onto Section 5, where we develop our analysis of transitive behar, we want to emphasize that, under Harves \& Kayne's proposal, the "transitive" properties of modal need do not directly follow from an incorporation operation of need, but rather from the fact that have can take complements and assign accusative Case. What the incorporation analysis does is liberate the verb so that, instead of checking the case features of need, it checks the case feature of the complement of need. In the analysis we defend in this paper, where behar is a nominal predicate, the issue of how this element checks its Case feature does not arise even if behar does not incorporate onto have, as predicates need not be assigned Case.

In the following section we develop our analysis of behar.

\section{Building a denominal modal}

\subsection{The underlying structure of transitive modal behar}

\footnotetext{
13 - $k o$ is an adpositional suffix that can directly attach to bare NPs, as well as some postpositional phrases (see Goenaga, 2003, and Artiagoitia, this volume).
} 
Revised version to appear in

U. Etxeberria, R. Etxepare and M. Uribe-Etxebarria (eds)

DPs and Nominalizations in Basque. John Benjamins.

Following our earlier work (Etxepare \& Uribe-Etxebarria 2010a), we will argue that the constructions involving transitive modal behar under analysis derive from an underlying structure, represented in (44a), where behar starts out as the nominal predicate of a small clause and the content of the need is the subject of this small clause. ${ }^{14}$ As shown in (44b), the experiencer of the need is related to the small clause by means of an adposition, akin in its function to applicative morphemes. The incorporation of this adposition to a higher raising predicate BE yields the so-called transitive auxiliary edun "have" in Basque. As we will show in Section 6, the analysis of have as a derived verb is independently attested in Basque for configurations other than the strictly modal ones.

(44) a. [Small Clause $\left\{\begin{array}{l}\mathrm{DP} \\ \text { Non-finite verbal XP }\end{array}\right\}$ behar ]

$$
\text { b. ...BE }\left[\begin{array}{lll}
\mathrm{PP} & \mathrm{DP} & \mathrm{P}
\end{array} \text { SMmall Clause }\left\{\begin{array}{l}
\mathrm{DP} \\
\text { Non-finite verbal XP }
\end{array}\right\} \text { behar ] }\right]
$$

The underlying clausal configuration we propose for Basque necessity modals in (44b) is reminiscent of the type of nominal modal constructions we find in other languages, and in particular of the type we find in some Celtic languages, as discussed among others by Siadhail (1989), Hickey (2009) and Hansen \& de Haan (2009) for Irish Gaelic, and by Noonan (1993) and Ramchand (1997) for Scottish Gaelic. In Scottish Gaelic, for instance, necessity modal constructions may be expressed by means of structures of the type illustrated in (45) (from Ramchand, 1997:150). In this example, the phrase to buy a house is the complement of the modal expressing obligation or necessity and the obligatory prepositional phrase is necessarily construed as the 'required buyer'. To account for the interpretation of the embedded subject, Ramchand assumes that the complement phrase contains a controlled subject position (PRO).

$$
\begin{aligned}
& \text { Bu choir dhombh [ PRO taigh a cheannach] } \\
& \text { Obligation to+me house } 3 \mathrm{p} \text { buy-VN } \\
& \text { 'I should buy a house' }
\end{aligned}
$$

Irish too has the option of expressing obligation in modal constructions with the structure illustrated in (46), from Hickey (2009:6); this construction "uses the word éigean 'compulsion, obligation' and a prepositional pronoun $-d e+$ personal pronoun which expresses relevance to an individual" (Hickey op.cit.: 6). The Irish example in (45b), which we borrow from Hansen \& de Haan (2009: 77), further illustrates this type of modal construction. The interpretation of these examples leads us to conclude that

\footnotetext{
${ }^{14}$ Unless we assume that Basque is head final, the fact that in the type of constructions under analysis behar precedes the Auxiliary has to be taken as an indication that it has undergone leftward movement. Haddican (2008) provides strong evidence that this is so. Although we will not enter into the discussion of word order in modal constructions in this paper, we follow this author in assuming that behar, or a projection containing this head, moves syntactically from its base position. See Etxepare \& UribeEtxebarria (2009) for independent evidence in favor of this analyisis. We leave open for further research what exactly the final landing site of behar is.
} 
Revised version to appear in

U. Etxeberria, R. Etxepare and M. Uribe-Etxebarria (eds)

DPs and Nominalizations in Basque. John Benjamins.

the DP introduced by the adposition and the subject of the embedded predicate must be correferential, in the same way that they were correferential in Scottish Gaelic.

(46) a. B'éigean dúinn cinneadh a dhéanamh.

(Hickey 2009) was compulsion to-us decision COMP make-VN

'We had to make a decision.'

b. Tá feidhm orm teach a thógáil be-prs need on me house PTL build-VN 'I need to build a house'

(Hansen \& de Haan 2009)

We propose that Basque necessity modals have a structure akin in many respects to the Celtic modal constructions illustrated in (45-46). Unlike the structure proposed by Ramchand in (45), however, we take the necessity modal noun behar and the content of the necessity to form an independent clausal constituent that we label as a "Small Clause":

$$
\text { [Small Clause }\left\{\begin{array}{l}
\mathrm{DP} \\
\text { Non-finite verbal XP }
\end{array}\right\} \text { behar ] }
$$

(47) represents a predicative relation between the noun behar 'need' and the content of the need, expressed by the subject of the small clause. The structure of the small clause represented in (47) leaves the DP for which the need or obligation is relevant (the DP that is interpreted as having the need or obligation), outside this predicative relation. This DP, which we have been informally referring to as the experiencer of the need/obligation, merges to the clausal structure by means of an adposition $(\mathrm{P})$, as in (48).

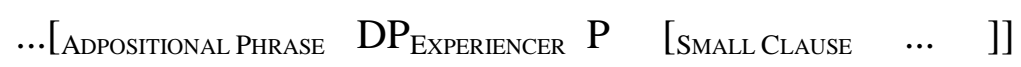

This entire PP is, in turn, the complement of a copula BE into which, we assume, the adposition incorporates:

$$
\text { ...[vp BE [ Experiencer P [Small Clause } \ldots \text { need ] }]
$$

In order to account for the Obligatory Control interpretation that these structures have (the DP to which we have referred as the experiencer obligatorily controls the subject of the non-inflected predicate sitting in the subject of the small clause), for the time being we will assume, in the spirit of Ramchand (1997), that this DP controls a null subject PRO in the non-finite complement, roughly as in (50).

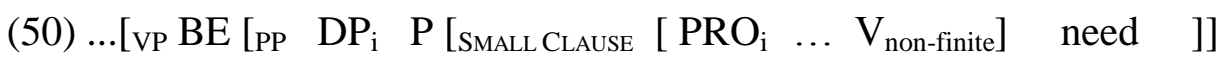

The incorporation of the adposition in (50) into BE, a raising verb, yields the transitive auxiliary edun 'have' (in the spirit of Kayne, 1993).

We assume that the experiencer checks Ergative case when it raises to Spec of $\mathrm{T}$ (see Rezac, Albizu and Etxepare, 2011 for arguments in favour of ergative checking in T) after the incorporation of $\mathrm{P}$ to $\mathrm{BE}$ and the subsequent derivation of a transitive verb. The 
Revised version to appear in

U. Etxeberria, R. Etxepare and M. Uribe-Etxebarria (eds)

DPs and Nominalizations in Basque. John Benjamins.

complex auxiliary, which as a result of the incorporation operation includes a Case licensing adposition, is thus available to check the case of a nominal in the subject of the small clause. The nominal behar, being a predicate, does not require a case licensor.

\subsection{Arity operations with modal behar}

One revealing property of the necessity modal construction in Basque concerns the limited extent to which it yields to arity operations like reflexivization and reciprocalization.

Basque has two strategies to construct a reflexive predicate: one is by means of the body-part reflexive possessive pronoun + buru "one's head", and the other one is by detransitivizing the verb, in which case the auxiliary is the intransitive izan "be". This is a strategy shared by inherent reflexives such as garbitu "wash" (51a), which do not admit the body part reflexive (51c) despite the fact that they take ordinary objects (51b), as well as by non reflexive verbs such as ikusi "see" (52a), which can reflexivize by means of the body-part reflexive (52b) or via insertion in an intransitive structure (52c):

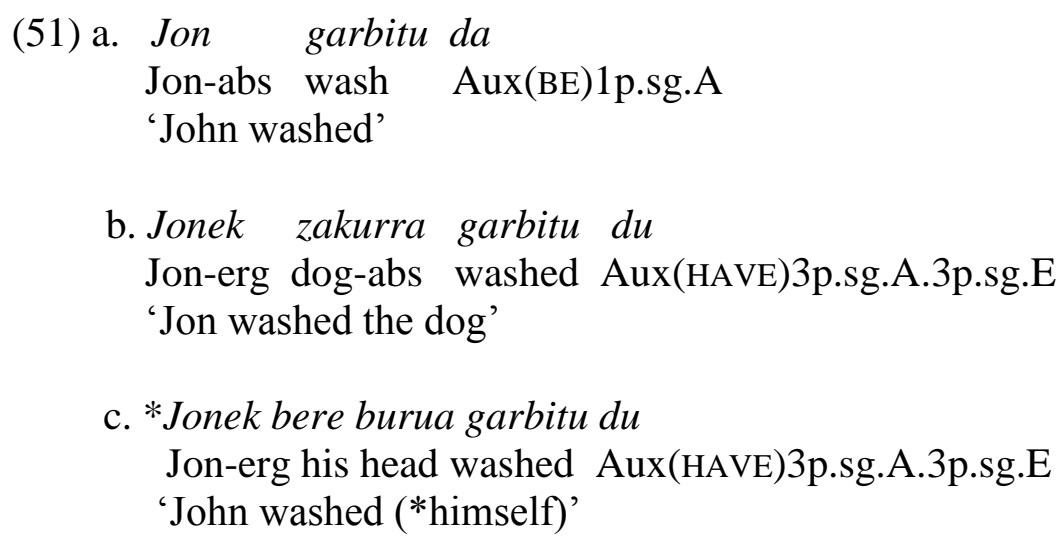

(52) a. Jonek zakurra ikusi du Jon-erg dog-abs seen Aux(HAVE)3p.sg.A.3p.sg.E 'Jon saw the dog'

b. Jonek bere burua ispiluan ikusi du Jon-erg his head mirror-det-in seen Aux(HAVE)3p.sg.A.3p.sg.E 'John saw himself in the mirror'

c. Jon ispiluan ikusi da Jon-abs mirror-det-in seen Aux(BE)1p.sg.A

'Jon saw himself in the mirror'

The detransitivization strategy is not circumscribed to reflexive predicates, but is shared by a wider spectrum of valency affecting operations. It is an option to express reciprocal 
Revised version to appear in

U. Etxeberria, R. Etxepare and M. Uribe-Etxebarria (eds)

DPs and Nominalizations in Basque. John Benjamins.

relations, as well as impersonals, middles and inchoatives (see Etxepare, 2003). ${ }^{15}$ In the case of reciprocals, the intransitivization strategy alternates with an overt reciprocal pronoun elkar "each other":

(53) a. Bilkura-n ikusi dira

Meeting-in seen $\operatorname{Aux}(\mathrm{BE}) 1 \mathrm{p} . \mathrm{pl} . \mathrm{A}$

'They saw each other in the meeting'

b. Bilkuran ikusi dute elkar meeting-in seen Aux(HAVE)3p.sg.A.3p.pl.E each other 'They saw each other in the meeting'

One intriguing property of modal behar constructions is that they are impossible in the intransitive reflexive configurations. The impossibility of the detransitivization strategy is apparent in the ungrammaticality of $(54 a, b) .{ }^{16}$

(54) a. *Jon behar da

Jon need Aux(BE)1p.sg.A

'Jon needs himself'

b. *Jon eta Miren behar dira

Jon and Miren need Aux(BE)1p.pl.A

'Jon and Miren need each other'

Compare the Basque cases with the Spanish verb necesitar "need", related to the noun necesidad "need". The derived verb behaves as a transitive verb regarding reflexivization and reciprocalization. Both can be expressed by means of an arity operation that absorbs the internal argument (see Reinhart and Siloni, 2004, 2005 and references therein). The presence of the clitic se in Spanish signals the underlying transitive status of the verb (see Koontz-Garboden, 2007 and references therein):

(55) a. Juan se necesita (a sí mismo)

Juan CL needs $\quad \mathrm{P}$ se self

'Juan needs himself'

b. Juan y María se necesitan

Juan and Maria CL need

'Juan and Maria need each other'

\footnotetext{
${ }^{15}$ From this perspective, intransitive constructions are reminiscent of the romance SE constructions. See Grimshaw (1982), Burzio (1986), Mendikoetxea (1999), Labelle (2008), among others, for a discussion of the basic facts in Romance.

16 The body-part anaphor is possible in those configurations under contexts identical to (57). The reciprocal anaphor is not. For a detailed discussion on arity operations in Basque and on the restrictions affecting the nominal reciprocal anaphor, see Etxepare (2011).
} 
Revised version to appear in

U. Etxeberria, R. Etxepare and M. Uribe-Etxebarria (eds)

DPs and Nominalizations in Basque. John Benjamins.

Although (55a) is admittedly bizarre in pragmatic terms, it is acceptable in a context where a distinction between Juan and his potentially different selves becomes available:

Juan se necesita (a sí mismo) en plena forma para la entrevista de mañana Juan SE needs (prep himself) in good shape for the interview of tomorrow "Juan needs himself in good shape for the interview tomorrow"

Similar examples can be constructed for English need constructions (from the internet):

\section{Socrates $_{1}$ needs Hippias as much as he needs himself $_{1}$}

Nothing of this sort can be constructed with the intransitive reflexive construction in Basque. In this regard, the Basque intransitive reflexive construction contrasts with the body-part anaphor $(58 \mathrm{a}, \mathrm{b})$ :

\section{a. Xabierrek bere burua prest behar du biharko elkarrizketa-rako} Xabier-erg his head ready need has tomorrow-gen interview-for 'Xabier needs himself ready for the interview tomorrow'

b. *Xabier prest behar da bihar-ko elkarrizketa-rako

Xabier ready need is tomorrow-gen interview-for

'Xabier needs himself ready for the interview tomorrow'

The Spanish (56b) involves an ordinary reciprocal predicate. Nothing like (56b) can be directly constructed with the Basque intransitive reflexive, unlike what happens with ordinary transitive verbs.

\subsubsection{Pure reflexives and near-reflexives}

In recent approaches to binding (see Reinhart and Reuland, 1993 and much subsequent work), reflexivity is a property of predicates, not a property of pronominal items. On this view, the role of reflexive pronouns is not to express coreference but to reflexivize predicates. Reflexive marking of a predicate can be realized lexically (sometimes through a verbal affix) or syntactically (through a SELF anaphor). As observed by Reuland (2001), lexically reflexive predicates and predicates reflexivized by a complex SELF anaphor make different contributions to the kind of reflexive interpretation conveyed by the predicate. The distinct contribution of lexical and syntactic reflexivity is apparent in contexts such as the Madame Tussaud examples first discussed by Jackendoff (1992). As a concrete instantiation of this context, imagine that Ringo Starr goes into Madame Tussaud's wax museum, which contains a statue depicting him. Upon seeing the statue, Ringo is bothered because the museum has chosen to portray him with a beard, though he himself prefers a shaven look. He decides to take out his razor and shave the statue that portrays him. Reuland notes that in this context, it is felicitous in Dutch to say (59b), which contains an inherently reflexive-marked predicate, but not (59a), a transitive predicate with a reflexivizing SELF anaphor:

(59) a. Ringo scheert zich

Ringo shaves SE

'Ringo shaves himself' (Ringo $\neq$ statue) 
Revised version to appear in

U. Etxeberria, R. Etxepare and M. Uribe-Etxebarria (eds)

DPs and Nominalizations in Basque. John Benjamins.

\section{b. Ringo scheert zichzelf \\ Ringo scheert SELF \\ 'Ringo shaves himself' (Ringo=statue)}

Conversely, it could happen that the statue Ringo discovers at the wax museum is one that doesn't have a bear. Watching it, Ringo realizes that he looks much better without a beard: he pulls out his razor and begins to shave his own face. In this context, Reuland notes, (59a) is felicitous but (59b) is not. Lidz (2001) points out that the same distinction arises in Kannada between the lexically marked reflexive predicates and those reflexive-marked by a complex anaphor. In the context put forward by Lidz, Ringo Starr enters the wax museum and finds his own statue there. If the verb is lexically reflexive-marked (via a reflexive morpheme internal to the verbal form), the statue interpretation is blocked, and it is himself that Ringo must see (for instance, in a mirror). When the predicate is reflexive-marked by the complex anaphor, the statue interpretation becomes available (Lidz, 2001:128):

(60) a. Hari tann-annu nood-i-kond-a

Hari self-ACC see-PP-REFL.PST-3SM

'Hari saw himself' (Hari $\neq$ statue)

b. Hari tann-annu-taanne nood-id-a

Hari self-ACC-self see-PST-3SM

'Hari saw himself' (Hari = Hari or statue)

The two Basque reflexive strategies differ along the same lines (see Etxepare 2011). Take the verb ikusi "see", which admits both the complex anaphor and the intransitive options. In the same context as the Kannada cases, (61a) is perfectly fine, but (61b) is pragmatically odd (assuming that the referent of John Lennon can only correspond nowadays to a statue):
a. Ringok bere burua ikusi du
museoan, Ringo-erg his head-abs seen Aux(HAVE)3p.sg.A.3p.sg.E museum-in
John Lennon-en ondoan
John Lennon-genit vicinity-in
'Ringo saw himself in the museum, next to John Lennon'
c. Ringo museoan ikusi da, \#John Lennon-en ondoan Jon-abs mirror-det-in seen Aux(BE)1p.sg.A , J.L-genit vicinity-in 'Ringo saw himself in the museum, next to John Lennon" (Ringo $\neq$ statue)

In the same context of elicitation as the Kannada sentences, only (61a), with a complex body-part anaphor, is felicitous in the statue reading.

Comparative deletion constructions provide another context where the two types of reflexive relation are distinguished. The lexically reflexive-marked predicates allow only a sloppy interpretation, while the syntactically reflexive-marked predicates allow 
Revised version to appear in

U. Etxeberria, R. Etxepare and M. Uribe-Etxebarria (eds)

DPs and Nominalizations in Basque. John Benjamins.

either a strict or a sloppy reading (Sells, Zaenen and Zec, 1987). Lidz provides the following Kannada cases (62a,b) to illustrate this asymmetry (Lidz, 2001:129):

(62) a. Rashmi Siita-ginta cheenage tann-annu rakshisi-koll-utt-aale Rashmi Sita-comp better self-acc defend-refl-npst-3sf 'Rashmi defends herself better than Sita defends herself'

*'Rashmi ${ }_{i}$ defends herself better than Sita defends her ${ }_{i}$ '

b. Rashmi Siita-ginta cheenage tann-annu-taane rakshis-utt-aale Rashmi Sita-comp better self-acc-self defend-npst-3sf 'Rashmi defends herself better than Sita defends herself' 'Rashmi ${ }_{i}$ defends herself better than Sita defends her ${ }_{i}$ '

The same asymmetry between sloppy and strict readings arises in the case of the two reflexivization strategies in Basque. Only in the presence of the body-part anaphor is a strict reading possible (63b), as opposed to (63a):

(63) a. Miren bere abokatua baino hobe defendatu zen

Miren his lawyer-D but better defended Aux(BE).past

'Miren defended herself better than the lawyer defended himself'

*"Miren ${ }_{i}$ defended herself better than the lawyer defended her ${ }_{i}$ "

\section{b.Mirenek bere abokatuak baino hobe defendatu zuen bere burua}

Miren-erg his lawyer-erg but better defended Aux(HAVE).past his head-abs 'Miren defended herself better than the lawyer defended himself'

'Miren defended herself better than the lawyer defended her $_{i}$ '

The Madame Tussaud's examples, as well as the comparative deletion cases show that SELF anaphors allow an interpretation in which the anaphor is referentially dependent on its antecedent, but is not necessarily identical with it. Lidz (2001) calls such anaphors near-reflexives. The difference between near-reflexive predicates and semantically reflexive predicates is shown in (64) (Lidz, 2001:129):

(64) a. $\lambda x[P(x, x)]$

b. $\lambda x[P(x, f(x)]$

(semantic/pure reflexive)

(near-reflexive)

(64a) indicates that the two arguments of the predicate $\mathrm{P}$ are identical, or that one single entity realizes both roles of the predicate. In (64b), the second argument is a function taking the first argument as input and returning an entity that is representationally related to that argument (Reuland, 2001:481). In many cases, those two representations will be extensionally identical. The near-reflexive function does not prohibit the antecedent and the anaphor from being the same entity in the world, particularly if $f$ can be the identity function. On the other hand, in pure reflexive anaphoric relations the anaphor and its antecedent must be identical. This may account for the fact that the intransitive reflexivization strategy, unlike the body-part anaphor in Basque, forces de se readings. To illustrate this fact, consider a context where a group of painters examines an old file with drawings from the art school of their youth. One of them, let's call it Xabier, pulls out an old drawing that he finds extraordinary and starts to praise it. He doesn't remember that the painting is his (many years have elapsed since art-school), 
Revised version to appear in

U. Etxeberria, R. Etxepare and M. Uribe-Etxebarria (eds)

DPs and Nominalizations in Basque. John Benjamins.

but Jon, who is next to him, does. In that context, Jon can say (65a), but cannot say $(65 b)$ :

(65) a. Xabierrek bere burua goraipatu du, baina ez da konturatu

Xabier-erg his head-abs praised has but neg is realized

'Xabier praised himself, but he didn't realize'

b. Xabier goraipatu da, \# baina ez da konturatu

Xabier praised is, but neg is realized

'Xabier praised himself, but he didn't realize'

The intransitive reflexives therefore, require strict identity between the arguments coindexed in the anaphoric relation, as in (64a). The logical representation in (64a) also allows us to derive the sloppy reading under the relevant predicates. Thus, the sloppy reading obligatory in the case of (62a) and (63a) follows as a result of copying the semantic predicate of the antecedent (65a) in the elided site at LF (66b), and applying the subject arguments (66c) (see Lidz, 2001 for details and a semantic account of the strict readings in the context of this hypothesis):
a. $\lambda x[\operatorname{defend}(x, x)]$
b. $\lambda x[\operatorname{defend}(\mathrm{x}, \mathrm{x})]($ she $)$ better than $\lambda \mathrm{x}[\operatorname{defend}(\mathrm{x}, \mathrm{x})]($ Peter $)$
c. [defend (she, she) better than [defend (Peter, Peter)]

Lexically or morphologically reflexive predicates, according to Lidz, never allow the near-reflexive interpretation. The generalization is captured by his Condition R (Lidz, 2001:131):

\section{Condition $\mathrm{R}$}

$$
\begin{array}{lc}
\lambda x[P(x, x)] & ->(\theta 1=\theta 2) \\
\text { semantics } & \theta \text {-grid }
\end{array}
$$

The condition states that if a predicate is semantically reflexive, then it must be lexically reflexive. Similarly, if a predicate is lexically reflexive, then it must be semantically reflexive. By stating the generalization as an identity condition on the reference of thetaroles, Lidz's condition $\mathrm{R}$ comes close to those analyses that view reflexivity as the result of an operation on the argument structure of predicates. One which comes particularly close to Lidz's condition R is Reinhart and Siloni's (2005) "bundling" operation, which takes two theta-roles and forms one complex theta-role. Reflexivization, as argued by Reinhart and Siloni, cannot be just a valency reducing operation as suggested in Chierchia (2004), but one that assigns two distinct roles to a single DP. The lexical operation that derives a reflexive predicate from a basic transitive one specifies that the roles associated to the verbal root apply to one and the same entity:

(68) a. Max washed

$$
\text { b. E(e) [wash (e) \& Agent (Max,e) \& Theme (Max,e)] }
$$


Revised version to appear in

U. Etxeberria, R. Etxepare and M. Uribe-Etxebarria (eds)

DPs and Nominalizations in Basque. John Benjamins.

In this sense, reflexivization for Reinhart and Siloni is not a valency reducing operation, but an operation that takes two theta roles and forms one complex theta-role:

(69) Reflexivization bundling

$\left[\theta_{\mathrm{i}}\right][\theta \mathrm{j}]->\left[\theta_{\mathrm{i}}-\theta \mathrm{j}\right]$, where $\theta_{\mathrm{i}}$ is an external $\theta$-role

The operation they call "bundling" operates on an external argument. It takes the internal argument of a predicate and bundles it with the external one, creating a single, but complex theta-role. In this sense, reflexivization is an arity operation parasitic on the presence of an external argument. Reinhart and Siloni show that the remaining overt argument of reflexive constructions shows properties typical of an external argument. The external status of the single overt argument of reflexive detransitivized predicates can be tracked down also in Basque. Thus, Albizu, Etxepare and Rezac (in progress) note that the absolutive DP of reflexive predicates is unlike the absolutive DP of inchoatives in that it does not alternate with the partitive case in polarity contexts:

(70) a. Ez da haurr-ik erori putzu horretan

Neg is child-part falled well that-in

'No child has fallen in that well'

\section{b.??Gaur ez da haurrik orraztu \\ Today neg is child-part combed \\ 'Today no child has combed his hair'}

The so-called "partitive case" is a special determiner associated to the existential interpretation of a DP in contexts of polarity, in a way parallel to, say, the genitive of negation in Russian (see Ortiz de Urbina, 1989). It alternates with the determiner in absolutive arguments, which occur either as objects of transitive predicates or as subjects of unaccusative ones. The partitive determiner cannot combine with an external argument, nor with an absolutive one if the latter is not the underlying object of the predicate. One case in point are the subjects of raising constructions built on adjectival (71) and nominal predicates (72):

a. Haurra gaixo dago

Child-D sick is-loc

'The child is sick'

b. ${ }^{*} E z$ da haurr-ik gaixo

Neg is child-part sick

'There is no sick child'

(72) a. Haurra artzain dago mendia-n

Child shepherd is mountain-in

'The child is (working as) a shepherd in the mountain'

b. *Ez dago haurr-ik artzain mendia-n

Neg is child-part shepherd mountain-in

'No child is (working as) a shepherd in the mountain' 
Revised version to appear in

U. Etxeberria, R. Etxepare and M. Uribe-Etxebarria (eds)

DPs and Nominalizations in Basque. John Benjamins.

If adjectives can only predicate by combining with a functional head that projects a specifier (see Hale and Keyser, 1993; 2002), then the absolutive of adjectival predications is external to the relevant predicate. The same property characterizes nominal predicates, if Baker (2003) is right in claiming that they cannot independently function as predicates, but require an independent copula to do so. As noted by Burzio (1986), adjectival and nominal predicates do not allow ne-extraction from their subject in Italian, either. To the extent that the possibility of ne-extraction diagnoses the predicate internal status of the argument from which extraction proceeds, the relevant arguments must be external in the sense of having been generated in a position outside the predicate.

\subsubsection{The coargument restriction}

For Reinhart and Siloni "bundling" is not in and of itself a lexical operation. They propose a parameter that distinguishes those languages where reflexivization ("bundling") operates in the lexicon, prior to the insertion of the lexical item in the syntax, and those languages where reflexivization operates at a syntactic level, in the course of the derivation.

If bundling operates in the lexicon, they argue, it can only apply to co-arguments. Many languages show co-argumenthood restrictions in their reflexivization strategies. For instance, reflexivization cannot apply across ECM constructions in languages like Hebrew or English (from Reinhart and Siloni, 2005:395): (OM=Object Marker)

(73) a. Dan maxsiv et acmo intiligenti

Dan considers OM himself intelligent

"Dan considers himself intelligent"

b. *Dan mitxasev intiligenti

Dan considers-refl intelligent

(74) a. Dan considers himself intelligent

b. *Dan considers intelligent

This restriction is not found in many other languages, however. Reflexivization in Romance languages for instance, can occur across two different predicates, as in Spanish (75a) or French (75b):

(75) a. Juan se considera [ _ inteligente $]$

Juan SE considers intelligent

'Juan considers himself intelligent'

b. Jean se voit [ _ laver les plats ]

Jean SE sees wahs the dishes

'John sees himself washing the dishes'

For those languages, Reinhart and Siloni claim that the reflexivization process is syntactic, and occurs along the derivation under conditions which are very similar to 
Revised version to appear in

U. Etxeberria, R. Etxepare and M. Uribe-Etxebarria (eds)

DPs and Nominalizations in Basque. John Benjamins.

those under which A-movement is possible. Reflexivization in Romance can thus spread across causative constructions:

$$
\begin{aligned}
& \text { a. Jean } s_{\mathrm{i}} \text { 'est fait [ inviter } \quad-\mathrm{i} \text { ce soir] } \\
& \text { Jean SE is made invite-inf tonight } \\
& \text { 'Jean got himself invited tonight' }
\end{aligned}
$$
b. Juan $\mathrm{se}_{\mathrm{i}}$ ha hecho [ invitar _ _i esta tarde] Juan SE has made invite-inf tonight 'Juan got himself invited tonight'

Nothing like this is possible in Basque, where the analogues of $(76 a, b)$ are completely out (see Etxepare 2011):

$$
\begin{aligned}
& \text { (77) a. Xabierrek Miren gonbidatu-arazi } d u \text { gaur gauean } \\
& \text { Xabier-erg Miren-abs invited-caus } \\
& \text { 'Xabier made invite Miren tonight" }
\end{aligned}
$$

\section{b. *Xabier gonbidatu-arazi da gaur gauean Xabier-abs invite-caus is today night-in 'Xabier got himself invited tonight'}

Causative verbs in Basque are created by affixation of the causative verb arazi "make" to the lexical verb. The causative structure is underlyingly biclausal, as shown by Ormazabal (1990b) and Oyharçabal (2002), with the final form being derived by incorporation of the embedded lexical verb to the bound causative verb (as in Baker, 1988). As we have just shown, complex predicate formation, a derivational phenomenon, does not license an intransitive reflexive in Basque. ${ }^{17}$

The Basque intransitive strategy is also sensitive to the thematic boundaries imposed by ECM constructions. We can compare in this regard the French (78a) (adapted from Reinhart and Siloni, 2005:413), with the unavailable Basque (79b), derived by intransitivizing (79a).

$$
\begin{aligned}
& \text { Jean } s_{\mathrm{i}} \text { 'entend [_ _ chanter] dans cet enregistrement } \\
& \text { Jean SE hears sing-inf } \\
& \text { 'Jean hears himself singing in that recording' }
\end{aligned}
$$
a. Jonek [Miren
kantatzen] entzun du Jon-erg Miren-abs singing
heard Aux(HAVE)3p.sg.A.3p.sg.E

\footnotetext{
17 This constitutes a potential argument against the idea that the difference between languages like Hebrew or Basque on the one hand and Italian or Spanish on the other, concerning the scope of the reflexivization strategy, may be due to the extent to which complex predicate formation is available. This is the view taken for instance by Baauw and Delfitto (2005). They claim that reflexivization is a process that applies at LF, and as such is sensitive to the creation of complex predicates along the derivation. The scope of the reflexivization operation encoded by the se clitic in Romance corresponds to the scope of complex predicate formation as a result of incorporation. The Basque causative cases seem to point to the conclusion that the level at which lexical reflexivity is defined does not correspond to the level at which complex predicates are formed.
} 
Revised version to appear in

U. Etxeberria, R. Etxepare and M. Uribe-Etxebarria (eds)

DPs and Nominalizations in Basque. John Benjamins.

\section{b. *Jon [ _ kantatzen] entzun da grabazio horr-etan \\ Jon sing-ger heard Aux(BE)3p.sg.A recording that-in \\ 'Jean hears himself singing in that recording'}

Arteatx (2007, this volume) shows that the first-merge position of Miren in (85a) is the embedded non-finite clause. However, the case and agreement properties of the subject of the perception complement correspond to the matrix clause. Thus, even if the external argument of the unergative verb kantatu ('sing') in (79) (the DP Miren) would show ergative Case in a finite clause under normal circumstances, in this construction it surfaces with absolutive Case. Absolutive Case is licensed by transitive predicates in their object position, so that the overall structure of the Basque perception complements seems to be very similar in this regard to that of ECM constructions in English. The external argument of the perception complement cannot check its case in the embedded non-finite clause and must rise to the higher verbal projection to do it (see also Rezac, Albizu and Etxepare, 2011). Under this analysis, the contrast between French and Basque follows from the different level at which the bundling operation applies: the lexicon for Basque, and the syntactic derivation for French.

The different status of the intransitivization strategy in Basque and Romance is also apparent in cases where non-lexical arguments are involved. Since non-lexical arguments are by definition absent from the theta-grid of the verb, no arity operation can be defined on them. The issue is different if bundling can operate along the derivation. One set of cases that distinguishes the two types of languages from each other are those related to the presence of a high applicative morpheme, in the sense of Cuervo (2003) or Pylkkanen (2001, 2008). Basque and French, for instance, contrast sharply in the availability of dative reflexivization. The latter is completely impossible in Basque (80c-d), but available in French (80a-b) (see Labelle, 2008). (80a-b) instantiate nonlexical datives, datives that cannot be part of the theta-grid of a lexical entry: ${ }^{18}$

(80) a. Jean s'est acheté une voiture

Jean SE is bought a car

'Jean bought himself a car'

b. Jean s'est coupé les cheveux

Jean SE is cut the hair

'Jean got a haircut'

c. *Xabier auto bat erosi da / zaio /du

\footnotetext{
${ }^{18}$ In the case of ( $\left.80 \mathrm{~b}\right)$, the dative is the underlying possessor of the body-part cheveux "hair". In that sense it is not an independent argument but part of the theme argument of the verb. In (80a), the reflexive clitic cannot be doubled by a nominal anaphor in argument position, unlike in truly thematic dative arguments. Compare in this regard (ia,b):
}

(i) a. *Jean s' est acheté une voiture à lui/soi-même

Jean CL is bought a car to himself

'Jon bought himself a car'

b. Jean s' est envoyé une lettre à lui-même

Jean CL is sent a postcard to himself

'Jean sent himself a postcard' 
Revised version to appear in

U. Etxeberria, R. Etxepare and M. Uribe-Etxebarria (eds)

DPs and Nominalizations in Basque. John Benjamins.

Xabier car one bought is

'Xabier bought himself a car'
Aux(3psgA)/3psgA3psgD/3psgA3psg.E

d. *Xabier ilea moztu da $\quad$ / zaio $\quad / d u$
Xabier-abs hair-abs cut
'Xabier got a haircut' $\quad$ Aux(3psgA)/3psgA3psgD/3psgA3psg.E

The ungrammaticality of the examples in (80c-d) holds no matter what auxiliary forms are selected. This includes the forms that contain an agreement index for the indirect object (cf. zaio) or the object (cf. $d u$ ). ${ }^{19}$ In other words, it is not because of Case considerations that the indirect objects in $(80 \mathrm{c} . \mathrm{d})$ cannot enter into the detransitivization strategy, since they are bad irrespective of the particular form of the Auxiliary selected. The reason for the ungrammaticality of (80) therefore must be strictly lexico-semantic.

In the context of the lexical restrictions on the Basque reflexive strategy, the ungrammaticality of (80c-d) follows straightforwardly from the fact that the relevant relations between the event and the dative arguments in question cannot be established at the right level: at the lexical level, those relations do not exist. ${ }^{20}$

\footnotetext{
${ }^{19}$ The examples with the transitive auxiliary $d u$ are bad under the reflexive reading, obviously.

${ }^{20}$ One exception to the behavior of ECM predicates is the Spanish/French borrowing kontsideratu $(<\mathrm{Sp}$.

Considerar/Fr. Considerer). It seems to admit the intransitivization strategy:
}

(i) [ _ azkarrak $]$ kontsideratzen gara Intelligent-D.pl consider-ger we-are 'We consider ourselves intelligent'

Basque kontsideratu presents the following intriguing properties vis-à-vis the other ECM contexts: first, the intransitive predicate only has a reflexive interpretation (iia), not a reciprocal one (unlike, say, Spanish considerar in (iib)):

(ii) a. Xabier eta Miren azkarrak kontsideratzen dira (reflexive/*reciprocal) Xabier and Miren intelligent consider-ger are

'Xabier and Miren consider themselves/*each other intelligent'

b. Javier y María se consideran (el uno al otro) inteligentes

Javier and María SE consider each other intelligent

'Javier and María consider themselves intelligent'

'Javier and María consider each other intelligent'

The second one concerns modifiability by temporal adverbs. Romance consider admits double modification:

(iii) a. Los viernes, Javier se considera atractivo los jueves. Siempre anda un día más tarde. Fridays, Javier SE considers attractive on Thursdays. Always walks one day late. 'On Fridays, Javier considers himself attractive on Thursdays. He's always one day late'.

b. *Ostiraletan Xabier ostegunetan kontsideratzen da erakargarria Fridays-in Xabier Thursdays-in consider-ger is attractive

Double modification suggests that underlying consider in Romance, there is a bi-clausal structure, with potentially two event arguments to locate temporally. No parallel implication results from the Basque case. The absence of a reciprocal interpretation and the lack of independent temporal modification suggest that the Basque intransitive consider behaves as a lexical reflexive, closer to garbitu "wash" than to ikusi "see". Lexical reflexives in Basque of the garbitu "wash" sort do not have a reciprocal reading. The reader is referred to Etxepare (2011) for related discussion. We leave this for further research. 
Revised version to appear in

U. Etxeberria, R. Etxepare and M. Uribe-Etxebarria (eds)

DPs and Nominalizations in Basque. John Benjamins.

The intransitive reflexive forms are also impossible under lexically selected datives. Thus, no intransitive reflexive can be created out of ditransitive predicates like eman "give", or igorri "send". 21

(81) a. Jonek bere buruari gutun bat igorri dio

Jon-erg his head-dat letter one-abs sent aux[3sE-3sD-3sA]

'Jon sent a letter to himself'
b. *Jon gutun bat igorri $d a$ / zaio / du
Jon-abs letter one-abs sent $\operatorname{Aux}(3 \mathrm{psgA}) / 3 \mathrm{psgA} 3 \mathrm{psgD} / 3 \mathrm{psgA} 3 \mathrm{psg}$.E
'Jon sent a letter to himself'

(82) a. Jonek bere buruari sari bat eman dio

Jon-erg his head-dat prize one-abs given aux[3sE-3sD-3sA]

'Jon gave himself a prize'

b. *Jon sari bat eman da / zaio /du

Jon-abs prize one-abs given Aux(3psgA)/3psgA3psgD/3psgA3psg.E

'Jon gave himself a prize'

Etxepare (2003:381) observes that the body-part anaphors are forced into all syntactic contexts involving adpositional arguments. This is the case for instance with the locative argument of sinetsi "believe", which selects a locative argument in Basque:

(83) a. Jonek Mirenengan sinesten du

Jon-erg Miren-loc believe-hab aux[3sE-3sA]

'Jon believes in Miren'

b. Jonek bere buruarengan sinesten $d u$

Jon-erg his head-loc believe-hab aux[3sE-3sA]

'Jon believes in himself'

c. *Jon sinesten da

Jon-abs believe-hab is

'Jon believes in himself'

As shown in (83), the locative argument of (83) blocks the coindexation of the DPs Miren (the complement of the adposition) and of the subject Jon. The reason is that Miren and Jon in this case are not co-arguments: only the subject and the entire PP are (see Reinhart and Reuland, 1993, for similar configurations).

The generalization can be extended to dative arguments if the latter are also headed by an adposition, as argued for by Albizu (2001) and Etxepare (2011), and Etxepare and Oyharçabal (in press). The lexical operation underlying the intransitive reflexive cannot operate across the PP. It is the PP that constitutes the argument of the predicate, not the

\footnotetext{
${ }^{21}$ See Levin and Rappaport (2008) for the selected status of the dative arguments of give and send.
} 
Revised version to appear in

U. Etxeberria, R. Etxepare and M. Uribe-Etxebarria (eds)

DPs and Nominalizations in Basque. John Benjamins.

DP it selects. Therefore, no co-argument relation can be established between the subject in (81) or (82), and the DP included in the dative phrase.

\subsubsection{Back to necessity modals}

With this much background, let us now come back to necessity modals and explain how we derive the properties they exhibit with regard to arity operations.

We have shown above that the intransitive reflexivization strategy cannot apply to modal constructions like the ones illustrated in (54), repeated below as (84).

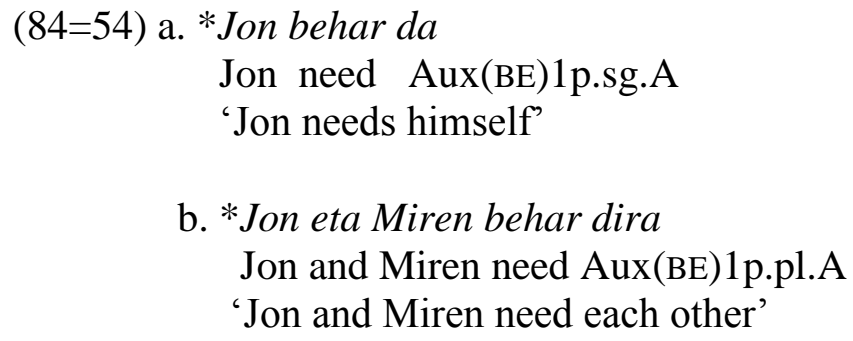

From the perspective of the restrictions operative on this strategy, the reason must be that, despite appearances, the two arguments associated to behar in the type of structure under analysis are not co-arguments. Note that this is a problem for any analysis that treats behar as lexical verb, since both the subject and the object would be co-arguments of behar. However, as we will show now, this comes as a natural result from the underlying structure we have proposed in Section 5.1., which we repeat below for convenience. Recall that in this structure behar is the nominal predicate of a small clause, whose specifier position is occupied by the content of the need. Since in this case this element is simply a DP (and not a non-finite verbal projection), the underlying structure that corresponds to the examples in $(54=84)$ would be $(85)$.

$$
\text { (85) ...[ve BE [pP DP1 P [Small Clause [ DP2] need ]] }
$$

Following the proposal we have made above, the surface subject of behar (DP1, the DP for which the need/obligation is relevant, the "experiencer") and the other DP (DP2, the content of the need) are introduced by different predicates. The subject is introduced by an adposition similar to applicative heads and external to the clause where the content of the need is introduced. DP2 is in turn selected by the nominal predicate behar. The intransitive reflexivization strategy is unavaible for examples like $(54=84)$ because DP1 and DP2 are not arguments of the same predicate in (85) and, consequently, no coargument relation can be established between the experiencer of the need and the content of the need in the lexicon.

\subsection{Intransitive predicative constructions with behar}

There is an interesting intransitive variant of the construction with behar, which we illustrate in (86): ${ }^{22}$

\footnotetext{
${ }^{22}$ The examples are drawn from the General Basque Dictionary, and span from the XVIth to the XXth century. The structure seems to have been limited to the eastern dialects historically, and it is not productive anymore, but has a sporadic literary use.
} 
Revised version to appear in

U. Etxeberria, R. Etxepare and M. Uribe-Etxebarria (eds)

DPs and Nominalizations in Basque. John Benjamins.

(86) a. Eta guziak dirade aiuta horr-en behar

And all-Abs are help that-genit need

'And all are in need of that help'

(Orotariko Euskal Hiztegia, vol IV. Pg. 312: Lç Ins E 7v)

b. Egiazki zu-re beharnaiz, zato enekin

Truly you-genit need am, come with-me

'Vraiament j'aurais bien besoin de vous' 'I truly need you'

(op.cit., vol IV. Pg. 312: Volt 211.)

c. Zue-n bear-bear da gure bazkuna; zuek nai zaituzte you-genit need-need is our society; you-abs want Aux

'Our society really needs you; they want you'

(op.cit., vol IV. Pg. 312: Ib. 146)

d. Zer-en bear zerate, ene neskatxok?

what-genit need are-you(pl), my girls

'What do you need, my girls

(op.cit., vol IV. Pg. 312: Zait Sof. 155)

In contrast with the modal constructions we have analyzed so far, all these constructions with modal behar involve intransitive Auxiliaries (the copula BE) and absolutive subjects. The construction in question is reminiscent of the English one in (87), with the caveat that there is no overt adposition present in the former:

\section{(87) I am in need of a new car}

A direct translation of the structures in (86) to English would yield something like (88):

\section{(88) *I am need of a new car}

The examples in (86c) and (86d) provide evidence that behar itself cannot be analyzed as an intransitive verb in this construction. In the case of (86c) this conclusion is based on the fact that behar is reduplicated. Reduplication does not take place with verbs, but can take place with other types of predicates -including some nominal predicates like haserre "anger", in (89a)-, and with secondary predicates in a small clause (89b).

(89) a. Haserre-haserre izateko, besterik ikusi behar nuen anger-anger to-be, other-part seen need Aux

'To be really angry, I needed to see other (further) things'

b. Jon poz-pozik ikusidut

Jon-A happy-happy see Aux

'I have seen Jon very happy' 
Revised version to appear in

U. Etxeberria, R. Etxepare and M. Uribe-Etxebarria (eds)

DPs and Nominalizations in Basque. John Benjamins.

The example in (86d) provides further evidence that behar is not an (intransitive) verb in this construction, as intransitive verbs do not take genitive objects in Basque. ${ }^{23}$ Finally, the word order facts found in examples like (90a) below also leads us to reject an analysis of behar as an intransitive verb in the construction in (88). The reason is that in (90) behar precedes Neg and Aux; however, as shown in (90b), Basque does not allow this word order in regular negative sentences involving verbal predicates. As (90c) illustrates, in the word order pattern of regular matrix negative sentences, both Negation and the auxiliary must precede the verb. The copular structure with intransitive behar in (86) differs in this regard from the modal constructions involving transitive behar we have focused on so far, since the word order pattern exhibited by the latter in negative clauses (both when the complement is a DP or when it is a noninflected complemente (90e)) is the one we find in regular negative clauses (90d).

(90) a. Eta egiaz, gizona beste ezeren bear ez da.

And truly, man-Abs other anything-genit need not is

'And truly, the man doesn't need anything else'

(Orotariko Euskal Hiztegia, vol IV. Pg. 312: Arr GB 136)

b. ?? Gizona hona etorriez da

man-Abs to-here come Neg is

'The man hasn't come here'

c. Gizona ez dahona etorri

man-Abs Neg is to-here come

'The man hasn't come here'

d. Ez dut

liburua behar

neg Aux(have)3p.sg.E-3p.sg.A book-A need

'I don't need the book'

e. $E z \quad d u t$

liburua irakurri behar

neg $\operatorname{Aux}($ have)3p.sg.E-3p.sg.A book-A read need

'I don't need to/don' have to read the book'

While the copular modal construction with behar discussed in (86-90) is reminiscent of the English copular modal construction to be in (the) need of in (87) and displays some features that set it apart from the the standard construction with transitive behar, it is however true that it also shares some properties with transitive behar constructions, which are not present in the nominal structures of the type be in (the) need of. First, the predicate of the copular construction in (86) can only be behar "need" and cannot just be any noun which happens to have a necessity interpretation; for instance, the noun premia 'urgent need' cannot form part of this type of construction despite the fact that it also encodes a meaning associated with need/obligation.

\section{(91) *Horren premia naiz}

\footnotetext{
${ }^{23}$ Genitive objects are only licensed in some well defined context within nominalizations involving the suffix - tze(a). See Duguine (2011, this volume) for extensive discussion of these constructions.
} 
Revised version to appear in

U. Etxeberria, R. Etxepare and M. Uribe-Etxebarria (eds)

DPs and Nominalizations in Basque. John Benjamins.

That-gen need am

'I need that'

In this sense, the intransitive copular construction with behar in (86) is identical to the denominal modal transitive construction with behar, which can only be built out of behar, and is not legitimate with just any noun meaning 'necesity' or 'obligation':

(92) a. Hori behar dut

That-abs need Aux(have)3p.sg.E-3p.sg.A

'I need that'

\author{
b.* Hori premia dut \\ that-abs need Aux(have)3p.sg.E-3p.sg.A \\ 'I need that'
}

The relevance of this fact becomes manifest once we note that structures directly parallel to the English be in (the) need of can be replicated in Basque with necessity nouns other than behar, as illustrated in (93), with the noun premia, impossible in the intransitive modal construction:

(93) a. You will be in (the) necessity of it

b. Xabier sendagile baten premia-n da

Xabier-abs doctor one-gen need-D-in is

'Xabier is an urgent need of a doctor

This suggests that whereas (93) is a construction that allows the nouns (need and behar/premia) to project their referential properties (as shown by the presence of a determiner, obligatory in the Basque construction and optional in the English one), both the intransitive behar construction in (86) and the transitive one do not allow this. This difference is possibly related to another property that distinguishes the intransitive behar construction in (86) from constructions of the type be in need of in (93d-f): only in the latter case can the noun be modified in Basque (94a), as it is in English (94d-f); behar in the intransitive construction in (86) cannot be modified at all (94b). In this regard, the intransitive construction (94b) behaves exactly like the transitive one (94c):

(94) a. Xabier sendagile bat-en behar gorri-a-n da

Xabier doctor one-gen need urgent-D-n is

'Xabier is in the urgent need of a doctor"

b. *Xabier sendagile baten behar gorri (a) da

Xabier doctor one-gen need urgent-D is

c. *Xabierrek liburu bat behar gorri $(a) d u$

Xabier-erg book one-abs need urgent-D has

'Jon urgently needs a book'

d. My best friend is in an urgent need of a divorce

e. US in strong need of appointing ambassador in Azerbaijan 
Revised version to appear in

U. Etxeberria, R. Etxepare and M. Uribe-Etxebarria (eds)

DPs and Nominalizations in Basque. John Benjamins.

f. Meanwhile, six patients that were in the urgent need of surgery have died.

Another important difference, which distinguishes the construction in (86) from the construction in (94a) is that, unlike in the latter, the intransitive behar cases must necessarily project an argument representing the content of the need. The difference between the two cases is exemplified in $(95 a, b)$. In (95b), the content of the need must be overtly realized. In (95a) this is not necessary.

(95) a. Xabier beharrean da

Xabier-abs need-D-in is

'Xabier is in need (Xabier is in a needy situation)'

b. Xabier *(horren) behar da

Xabier that-gen need is

'Xabier is in need of that'

All these properties lead us to conclude that the construction illustrated in (86) is therefore not a reduced version of the fully nominal construction be in (the) need of, but is rather the intransitive counterpart of transitive behar and also involves a small clause as part of its underlying structure. One last piece of data confirms that we need to distinguish the two constructions from each other: unlike the be in (the) need of construction in (94a), the intransitive behar construction in (86) is only compatible with stative aspect, realized by the copula izan "be". Thus, while behar in this case cannot combine with frequentative auxiliaries (96a), the Basque counterpart of the be in (the) need of constructions in $(93 \mathrm{~b}, 94 \mathrm{a})$ can be combined with frequentative auxiliaries (96b):

(96) a. *Xabier horren behar dabil

Xabier that-gen need walks

'Xabier is lately in need of that'

b. Xabier horren beharrean dabil

Xabier that-gen need-D-in walks

'Xabier is lately in need of that'

The idea that the transitive and the intransitive behar construction in (86) are closely related is thus supported by a substantive amount of evidence. The question at this point is what separates the two cases, with intransitive and transitive behar. One particularly trivial account of the differences would capitalize on the Case-licensing properties of each of the constructions. We have proposed that the transitive structure includes the following structure (97):

$$
\text { (97) ...[vp BE+P [ DP1 (P) [Small Clause [ DP2] need ]] }
$$

(97) involves a crucial component that serves to separate the DP for which the need or obligation is relevant (DP1, which we have informally referred to as the 'experiencer') from the need itself and its content (that is, from the small clause): a high adposition that introduces the subject of transitive behar (DP1, the experiencer). Despite the absence of any overt realization of an adposition in the intransitive cases, it is difficult 
Revised version to appear in

U. Etxeberria, R. Etxepare and M. Uribe-Etxebarria (eds)

DPs and Nominalizations in Basque. John Benjamins.

to see, on purely semantic grounds, how one would escape the conclusion that a tacit adpositional head, distinct from the need itself, relates the experiencer and the complex unit formed by behar and the content of the need in those cases too:

\section{(98) $\mathrm{Ni}$ horren behar naiz}

I-abs that-gen need am

'I need that (lit. I am need of that)'

Given the purely copular contribution of the finite auxiliary, it is hard to see how a reasonable compositional interpretation for $(86,98)$ could be derived without the help of extra syntactic material. Let us thus hypothesize that the intransitive behar constructions in (86) also present a tacit applicative head:

$$
\text { (99)...[vp BE [pP DP1 P [Small Clause [ DP2] need ]] }
$$

Unlike in the case of transitive behar, however, in the intransitive variant of the construction in (86), the applicative head does not incorporate. This means that the DP inside the small clause does not check its case outside the PP, but is forced to find a case inside the small clause. In a recent analysis of the distribution of the genitive suffix ren, Artiagoitia has convincingly argued that the suffix realizes both structural and inherent cases in Basque. In possessive constructions the genitive has the distribution of abstract case. Genitive case must occur in all arguments of complex possessive constructions (Artiagoitia, 2009:99), in the same way that DPs must be case-marked in finite contexts in this language (see Artiagoitia this volume $a, b$ ):

\section{(100) Artetaren Pitxitxiren erretratua \\ Arteta-gen Pitxitxi-gen portrait \\ 'Pitxitxi's portrait by Arteta'}

The genitive Case $-r e n$ differs from a second genitive suffix $-k o$, which has the distribution of a postposition, in that it only attaches to DP arguments of a nominal or a nominalized head (see also Goenaga, 2003). Genitive marked arguments in contexts such as (100) must occur right below the definite determiner but higher than the thematic layer where the possessive relation is defined, and the quantificational layer of the DP, a position that he takes to be derived by A-movement (see Artiagoitia, this volume a,b). Multiple genitive constructions such as the one in (100) show antireconstruction effects reminiscent of movement to A-positions, and give rise to Person/Case constraints of the sort observed in finite ditransitive constructions (Albizu, 1997; Ormazabal and Romero, 2008; Rezac, 2008). In comparison to abstract genitive case, Artiagoitia (2009) also argues that bare nouns in Basque can assign inherent genitive case. Inherent case has some crucial properties that distinguish it from structural genitive case: it cannot attach to more than one argument, and it always expresses the content of the bare noun. One of the relational nouns in Basque that admits a bare occurrence is the noun berri "news". The following pair, which illustrates this contrast, is borrowed from Artiagoitia (2009:106):

\section{(101)a. Telebistak Berria egunkariaren berri eman zuen}

Television-erg Berria journal-gen news given Aux(have)3p.sg.E-3p.sg.A

'The TV gave news about the journal Berria' 
Revised version to appear in

U. Etxeberria, R. Etxepare and M. Uribe-Etxebarria (eds)

DPs and Nominalizations in Basque. John Benjamins.

\section{b. Telebistak Berria egunkariaren berria eman zuen \\ Television-erg Berria journal-gen news-D given Aux(have)3p.sg.E-3p.sg.A \\ 'The TV gave news about the journal Berria' \\ 'The TV gave the news of the journal Berria'}

Whereas in the case of the bare noun berri "news" in (101a) the genitive complement can only express the content of the news (they are about a given journal), in the case where the noun has a determiner (101b), the meaning of the genitive complement can be either the content of the news or the element in possesion of the news (the possessor of the news). In the latter case, the sentence means something like "the TV gave the news that the journal Berria had spread". It is only under the second case that more than one genitive argument is possible:

\section{(102)Telebistak Berria-ren zezenketen berria eman zuen}

Television-erg Berria-gen bullfight-gen new-D given aux[3sE-3sA]

"The TV gave the news spread by the journal Berria concerning the bullfighting"

Those positional and interpretative restrictions lead Artiagoitia to conclude that there is a low syntactic position where genitive arguments can stay, and that unlike the higher positions, this one corresponds to a position where inherent case is assigned. The content restriction on the interpretation of arguments receiving inherent case can be immediately extended to the intransitive behar cases in (86): the genitive there marks the content of the need, not the possessor of the need, and it is the argument of a bare noun behar. We conclude therefore that the genitive DP in the small clause headed by behar receives inherent case from the noun or from some low syntactic projection of the noun.

\section{6. $P$ incorporation and transitive auxiliaries}

Our analysis leads us to merge the experiencer of the need in a position outside the constituent that includes the nominal predicate behar and the content of the need. This structure receives support from the parallelism we can establish with other languages that have nominal modals (Section 5.1.), from the binding asymmetries found between ordinary transitive verbs and behar (Sect. 5.2.), and from the nominal syntactic distribution of behar in intransitive behar constructions (5.3). It is also indirectly supported by the failure of the incorporation hypothesis (of the sort put forward for English need, for instance) to account for the whole set of relevant facts analyzed in the previous sections. The structure we propose is repeated here:

\section{(103) ...[vP BE [pP DP P [small Clause DP/non-finite clause behar]}

The alternative analysis we have proposed to the direct incorporation of the noun behar to a light verb have requires a particular analysis of the transitive auxiliary as a derived one. We have proposed that the experiencer of the need is merged in the derivation to a silent applicative head (represented as $\mathrm{P}$ in (103)), which may end up incorporating to the higher intransitive auxiliary verb BE, resulting in this case in the transitive auxiliary edun. The claim makes certain predictions regarding the status of the so-called transitive auxiliary in Basque: in order to make sure that our hypothesis is not ad-hoc, it must be 
Revised version to appear in

U. Etxeberria, R. Etxepare and M. Uribe-Etxebarria (eds)

DPs and Nominalizations in Basque. John Benjamins.

sustained by independent evidence that transitive auxiliaries in Basque may be derived from structures that involve an underlying applicative or prepositional head of some sort in contexts other than the modal ones studied in this work. As we discuss next, this prediction is borne out. Thus, it has been noted that the transitive auxiliary edun may introduce predicative structures where the subject is clearly an oblique argument, but nevertheless behaves as a transitive subject in terms of case and agreement. Consider in this regard (104) (from Etxepare, 2003:414):

\section{(104) Nik Xabier aspaldiko adiskidea dut I-erg Xabier-abs long-time-gen friend-D Aux(have)1p.sg.E-3p.sg.A \\ 'Xabier is an old friend to me' (lit.: I have Xabier an old friend)}

(104) involves a transitive clause with an ergative subject, an absolutive object and a nominal predicate. The ergative subject (the ergative first person pronoun nik) is interpreted as the person who is related to Xabier by friendship. The sentence can be paraphrased by Xabier is my friend or Xabier is a friend to me. The ergative subject only has that interpretation if both the nominal predicate (adiskidea in (104)) and the object (Xabier) are present. Otherwise, the subject can only be understood as the owner of Xabier:

\section{(105) Nik Xabier dut \\ I-erg Xabier-abs aux[3sE-3sA] \\ 'I have Xabier'}

In view of cases like (105), the question arises as to how exactly the ergative subject relates to the rest of the structure in (104). One possibility is that it is the underlying subject of a possessive phrase that has the nominal predicate as the possessed quality (my friend). The right paraphrase in this case would be something like Xabier is my friend:

$$
\text { (106)... [Small Clause Xabier [ my friend] }
$$

Another possibility would be that the ergative subject, just like in the behar cases, is merged to a basic predication that states that Xabier is a friend. An independent adpositional head puts together this basic predication with the first person subject:

$$
\text { (107)...[PP [Small Clause Xabier a friend] to me }]
$$

That a possessive relation between the ergative subject and the predicate is not definitional of the construction is shown by other cases where this relation cannot exist. In such cases, the ergative subject is simply an argument on whom the benefit or the interest of the underlying predication falls, and no possessive relation is implied between the subject and the predicate. Consider in this regard (110):

(108)Xabier mutilazkarra duzu /dugu / dute

Xabier-abs boy smart-D Aux(have)2p.sgE-3p.sgA/1p.plE-3p.sgA/3p.plE-3p.sgA

'Xabier is an intelligent boy, which benefits/interests you/us/them'

*'Xabier is your/our/their intelligent boy'

(Lit.: we/you/they have Xabier an intelligent boy) 
Revised version to appear in

U. Etxeberria, R. Etxepare and M. Uribe-Etxebarria (eds)

DPs and Nominalizations in Basque. John Benjamins.

It may be of interest to note that in the cases at hand, the transitive auxiliary does not freely alternate with the lexical possessive verb eduki ('have'):

(109) a. *Xabier mutil azkarra daukagu

Xabier-abs boy smart-D Have(lexical)3p.sg.A-1p.pl.E.

'Xabier is an intelligent boy, which benefits us'

b. *Xabier adiskidea daukagu

Xabier friend-D Have(lexical)3p.sg.A-1p.pl.E.

'Xabier is a friend, which benefits us'

This is an interesting fact, considering that the lexical verb of possession can alternate with the transitive auxiliary edun in ordinary possessive relations:

(110) a. Xabierrek adiskide bat du

Xabier-erg friend ona has

'Xabier has a friend'

b. Xabierrek adiskide bat dauka

Xabier-erg friend one has-lexical

'Xabier has a friend'

This suggests that the functional head that contributes the oblique theta-role on the subject (the "experiencer" role) is external to the relation between the object of the construction and the nominal predicate. In other words, the lexical entry of the verb of possession eduki "have" in Basque does not bear an argument slot for the kind of applicative head involved in this construction. One straightforward analysis for the cases under analysis is one where the subject starts out as the specifier of an applicative head, which assigns the oblique thematic role we have informally referred to as the "experiencer" (the DP for which the need of obligation is relevant):

(111) ...BE [PP I $\mathrm{P}_{\text {for }}[$ Xabier adiskidea] $]$ (Xabier is a friend for me)

Incorporation of $\mathrm{P}$ to $\mathrm{BE}$ produces the derived transitive auxiliary edun "have", and expands the domain where agreement and case checking relations can be established for the elements within the complement of $\mathrm{P}$ (the small clause).

If instead of adiskidea "a friend" we have behar "need", we have the same exact structure we have argued is the underlying structure involving the obligation modal behar in Basque in the previous sections:

(112) ..BE [ pP $\quad \mathrm{I} \quad \mathrm{P}_{\text {for }}$ [Small Clause Xabier behar] $]$

\section{Conclusion}

The paper has shown that necessity modal constructions in Basque, traditionally considered to be verbal constructions, are derived from a noun meaning need in a way 
Revised version to appear in

U. Etxeberria, R. Etxepare and M. Uribe-Etxebarria (eds)

DPs and Nominalizations in Basque. John Benjamins.

other than incorporation into a verbal structure. The Basque modal noun behar starts out as the nominal predicate of a clausal constituent that has the content of the need as its sole argument. The experiencer of the need (the subject of the construction) is merged independently, as the specifier of an adpositional head that assigns it an oblique role, much as applicative heads do. This adpositional head merges with the clausal constituent including the predicate noun behar and its content. The adpositional head can raise and incorporate to a higher intransitive auxiliary BE, giving rise to a transitive auxiliary, as in Kayne (1993). The hypothesis advanced here accounts for restrictions on behar constructions which are difficult to explain under the view that the modal behar is a transitive verb in Basque. Among the properties of behar constructions that naturally fall from our analysis are: (i) the absence of non-finite forms; (ii) the absence of intransitive reflexives directly constructed on behar; (iii) the clearly nominal distribution of the necessity modal in intransitive behar constructions; (iv) the derived status of the transitive auxiliary in the case of necessity modals, paralleled by other nominal predicative constructions outside modality where the transitive auxiliary can also be shown to be derived by incorporation of a tacit adposition. We also pointed out the parallels that the Basque modal construction presents with other known nominal modal constructions, as those found in some of the Celtic languages (Irish and Scottish Gaelic among others). We hope that the analysis put forward here, as well as the Basque data uncovered, can serve as a modest testing ground for the analysis of the nominal modal construction and its relation to verbal modals in other languages, a topic which remains yet to be extensively studied.

\section{REFERENCES}

Albizu, Pablo (1997) The Syntax of Person Agreement. Doctoral dissertation, University of Southern California.

Albizu, Pablo (2001) "Datibo sintagmen izaera sintaktikoaren inguruan:eztabaidarako oinarrizko zenbait datu" In Beatriz Fernandez and Pablo Albizu (eds) Kasu eta Komunztaduraren gainean/On Case and Agreement. Bilbao: University of the Basque Country. 49-70.

Arteatx, Iñigo, Xabier Artiagoitia eta Arantzazu Elordieta (arg). 2008. Antisimetriaren hipotesia vs. Buru parametroa: euskararen oinarrizko hitz hurrenkera ezbaian. Bilbo:Euskal Herriko Unibertsitatea.

Artiagoitia, Xabier (2009) "Jabetza-genitiboaren sintaxia eta erkatze anitzkuna" In Ricardo Etxepare, Ricardo Gómez and Joseba A. Lakarra (eds) Festschrift for Bernard Oyharçabal. Special Issue of the International Journal of Basque Language and Linguistics XLIII:1-2. 97-118.

Artiagoitia, Xabier (this volume, a) "The DP Hypothesis in the Grammar of Basque"

Artiagoitia, Xabier (this volume, b) "Genitive case and multiple checking in Basque" 
Revised version to appear in

U. Etxeberria, R. Etxepare and M. Uribe-Etxebarria (eds)

DPs and Nominalizations in Basque. John Benjamins.

Baauw, Sergio and Denis Delfitto (2005) "New views on reflexivity: Delay effects in Acquisition, Cross-modular Principle B and Reflexive Clitics in Romance" Probus, 172: $145-184$.

Baker, Mark (2003) Lexical Categories. Cambridge:Cambridge University Press.

Balza, Irene (2010a). Tense and aspect combinations in modal constructions: a crosslinguistic analysis. Ms. University of the Basque Country (UPV-EHU).

Balza, Irene (2010b). Clausal architecture and morpho-syntactic structure from the point of view of modal verbs. Ms. University of the Basque Country (UPV-EHU).

Bhatt, Rajesh. (1998). Obligation and Possession. In H. Harley (ed.), Papers from the UPenn/MIT roundtable on argument structure and aspect. MITWPL 32, pp. 21-40.

Borgonovo, Claudia \& Sarah Cummins (2007). "Tensed Modals". Correference, Modality and Focus ed. by Luis Eguren \& Olga Fernández Soriano, 1-18. Philadelphia/Amsterdam: John Benjamins.

Burzio, Luigi (1986) Italian Syntax: A Government and Binding Aproach. Dordrecht:Reidel.

Chomsky, Noam (2000) "Minimalist inquiries: the framework" In Roger Martin, David Michaels and Juan Uriagereka (eds) Step by Step: Essays on Minimalist Syntax in Honor of Howard Lasnik, eds., 89-155. Cambridge, Mass: MIT Press.

Condoravdi, C. (2002) 'Temporal Interpretation of Modals. Modals for the Present and for the Past.' In D. Beaver et. al. (eds.), Stanford Papers on Semantics, CSLI Publications. 59-82.

Demirdache, Hamida eta Myriam Uribe-Etxebarria (2008) “On the temporal syntax of non-root modals" In Jacqueline Lecarme eta Jacqueline Guéron (arg) Time and Modality. Dordrecht: Springer. 79-114.

Chierchia, Gennaro (2004) "A semantics for unaccusatives and its syntactic consequences". In Artemis Alexiadou, Elena Anagnostopoulou and Martin Everaert (eds) The unaccusativity puzzle. Oxford:Oxford University Press. 22-59.

Elordieta, Arantzazu (2001) Verb Movement and Constituent Permutation in Basque. Herbehereak: LOT Publications.

Etxepare, Ricardo (2003) "Valency and Argument Structure in the Basque Verb" In Jose Ignacio Hualde eta Jon Ortiz de Urbina (arg) A Grammar of Basque. Berlin:Mouton. 363-425.

Etxepare, Ricardo (to appear) "Contact and change in a restrictive theory of parameters" In Carme Picallo and Jose María Brucart (eds) Parameters and Linguistic variation. Oxford:Oxford University Press. 
Revised version to appear in

U. Etxeberria, R. Etxepare and M. Uribe-Etxebarria (eds)

DPs and Nominalizations in Basque. John Benjamins.

Etxepare, Ricardo (2011) Anaphors and reflexive strategies in Basque. Ms. Iker.

Etxepare, Ricardo \& Myriam Uribe-Etxebarria (2009). "Hitz hurrenkera eta birregituraketa euskaraz" In Ricardo Etxepare, Ricardo Gómez and Joseba A. Lakarra (eds) Festschrift for Bernard Oyharçabal. Special Issue of the International Journal of Basque Language and Linguistics XLIII:1-2. 335-356.

Demirdache, Hamida \& Myriam Uribe-Etxebarria (2008a) "Scope and Anaphora with Time Arguments: the Case of 'Perfect' Modals”. Lingua 118, 1790-1815.

Demirdache, Hamida \& Myriam Uribe-Etxebarria (2008b) "On the Temporal Syntax of Non-Root Modals". Time and Modality, 79-114. Dordrecht: Springer.

Demirdache, Hamida \& Myriam Uribe-Etxebarria (2009) “Aditz laguntzaile modalak eta irakurketa epistemikoa euskaraz" in J. Gorrotxategi et al. (eds.) International Journal of Basque Linguistics and Philology, ASJU 43.

Demirdache, Hamida \& Myriam Uribe-Etxebarria (2010) "Morphosyntactic variation in the temporal construal of non-root modals" In Bok-Bennema, Reineke, Brigitte Kampers-Manhe and Bart Hollebrandse (eds.), Amsterdam. John Benjamins. P. 77-104

Duguine, Maia (this volume) "Basque nominalizations and the role of structural Case in the licensing of null arguments"

Duguine, Maia (2011) Pro-drop and Linguistic Variation: A Minimalist Analysis. Doctoral dissertation, University of the Basque Country-University of Nantes.

Grimshaw, Jane (1982) "On the lexical representation of Romance reflexive clitics" In Joan Bresnan (ed.) The mental representation of grammatical relations. Cambridge, Mass.:MIT Press. 87-146.

Haddican, William (2001) "Basque Functional Heads" Linguistics in the Big Apple. CUNY/NYU Working Papers in Linguistics.

Haddican, William (2004) "Sentence Polarity and Word Order in Basque" The Linguistic Review 21:2, 81-124.

Haddican, William (2005) Aspects of Language Variation and Change in Contemporary Basque. Doktorego tesia, New York University.

Haddican, William (2008) «Euskal perpausaren oinarrizko espez-buru-osagarri hurrenkeraren aldeko argudio batzuk » In Iñigo Arteatx eta beste (arg). 69-96.

Haddican, William \& George Tsoulas (this volume) "A continuum of deficiency for Basque infinitives"

Hale, Ken. and Samuel. J. Keyser (1993). On argument structure and the lexical expression of syntactic relations. In The View from Building 20: Essays in Honor of 
Revised version to appear in

U. Etxeberria, R. Etxepare and M. Uribe-Etxebarria (eds)

DPs and Nominalizations in Basque. John Benjamins.

Sylvain Bromberger. Hale, K. and Keyser, S. (eds.) Cambridge, MA: MIT Press, 53109.

Hale, Ken and Samuel J. Keyser (2002) Prolegomenon to a Theory of Argument Structure. Linguistic Inquiry Monographs 39. Cambridge, Mass.:MIT Press.

Hansen, Björn and Ferdinand De Haan (eds) (2009) Modals in the Languages of Europe. Berlin: Mouton de Gruyter.

Harves, Stephanie, 2008. "Intensional Transitives and Silent HAVE: Distinguishing between Want and Need". Proceedings of the 27th West Coast Conference on Formal Linguistics, ed. Natasha Abner and Jason Bishop, 211-219. Somerville, MA: Cascadilla Proceedings Project.

Harves, Stephanie and Richard S. Kayne (2008). Having Need and Needing Have in Indo-European. Ms., Pomona College and New York University.

Hickey, Raimond (2009) "Modal Verbs in English and Irish" In Penttilä, Esa and Heli Paulasto (eds) Language Contact Meets English Dialects: Studies in Honour of Markku Filppula. Newcastle-upon-Tyne:Cambridge Scholars Publishing.

Hornstein, Norbert, Sara Rosen and Juan Uriagereka (1996) "Integral predication" In José Camacho, Lina Choueiri and M. Watanabe (eds) Proceedings of WCCFL 14. Stanford:CSLI Publications. 169-184.

Isačenko, Alexander V. (1974) "On have and be Languages: A Typological Sketch" In M.S. Flier (ed),Slavic Forum: Essays in Linguistics and Literature. The Hague:

Mouton. 43-77.

Jackendoff, Ray (1992) "Mme Tussaud meets the binding theory" Natural Language and Linguistic Theory 10:1-33.

Kayne, Richard (1993) "Toward a Modular Theory of Auxiliary Selection" Studia Linguistica 47:3-31.

Kayne, Richard S. "Need and Light Verbs". Talk delivered at the University of Siena, january 2009.

Koontz-Garboden, Andrew (2007) States, Changes of State and the Monotonicity Hypothesis. Doctoral dissertation, Stanford University.

Labelle, Marie (2008) "The French reflexive and reciprocal se" In Natural Language and Linguistic Theory 26:833-876.

Laca, Brenda. 2005. "On the Interaction of Modal Verbs with Tense and Aspect in Spanish”. Ms., University of Paris 8.

Laca, Brenda. 2008. "On modal tense and tensed modals". Invited talk at Chronos 8. 
Revised version to appear in

U. Etxeberria, R. Etxepare and M. Uribe-Etxebarria (eds)

DPs and Nominalizations in Basque. John Benjamins.

Laka, Itziar (1990) Negation in Syntax. On the Nature of Functional Projections and Projections. Doktorego tesia, MIT.

Levin, Beth and Malka Rappaport-Hovav (2008) "The English Dative Alternation: The Case for Verb Sensitivity" Journal of Linguistics 44: 129-167.

Lidz, Jeffrey (2001) “Condition R” Linguistic Inquiry 32-1:123-140.

Mendikoetxea, Amaia (1999) "Construcciones inacusativas y pasivas". In I.Bosque and V. Demonte (eds) Gramática Descriptiva de la Lengua Española, vol.2. Madrid:Espasa. $1575-1629$.

Noonan, Maire. (1993) "Statives, Perfectives and Accusativity: The importance of being Have," in J. Mead, ed., Proceedings of the West Coast Conference on Formal Linguistics 11, 354-370.

Ormazabal, Javier ( 1990) "Modal verbs in Basque and head-movement" In Joseba A. Lakarra eta Iñigo Ruiz Arzalluz (arg) Memoriae L. Mitxelena Magistri Oblatae. Pars Altera. ASJUko Gehigarriak 14. Donosita:Gipuzkoako Foru Aldundia. 835-845.

Ormazabal, Javier and JuanRomero (2008) "The object agreement constraint" Natural Language and Linguistic Theory 25-2:315-347.

Ortiz de Urbina, Jon (1989) Parameters in the Grammar of Basque. Kluwer:Dordrecht.

Ramchand, Gillian C. (1997) Aspect and Predication. Oxford: Oxford University Press.

Reinhart, Tanya eta Eric Reuland (1993) “Reflexivity” Linguistic Inquiry 24: 657-720.

Reinhart, Tanya and Tal Siloni (2005) "The Lexicon-Syntax Parameter:Reflexivization and Other Arity Operations" Linguistic Inquiry 36-3:389-436.

Reuland, Eric (2001) "Primitives of Binding” Linguistic Inquiry 32:439-492.

Rezac, Milan (2008) "Escaping the Person Case Constraint: Reference-set computation in the $\varphi$-system”. In Pierre Pica (ed.) Linguistic Variation Yearbook 2006: 97-138.

Rezac, Milan, Pablo Albizu and Ricardo Etxepare (2011) “Abstract Ergative Case”. Ms. SFL-CNRS, EHU, IKER-CNRS.

O’Siadhail, M. (1989) Modern Irish. Grammatical Structure and Dialectal Variation. Cambridge: Cambridge University Press.

San Martin, Itziar (this volume) "Structural Dependency and Interpretation in Basque Nominalized clauses"

Sells, Peter, Annie Zaenen, and Draga Zec (1987) "Reflexivization variation: Relations between syntax, semantics and lexical structure" In Masayo Iida, Stephen Wechsler and 
Revised version to appear in

U. Etxeberria, R. Etxepare and M. Uribe-Etxebarria (eds)

DPs and Nominalizations in Basque. John Benjamins.

Draga Zec (eds) Working papers in grammatical theory and discourse structure. Stanford: CSLI Publications. 169-238.

Uribe-Etxebarria, Myriam (1989a). On Noun Incorporation in Basque. Ms. University of Connecticut.

Uribe-Etxebarria, Myriam (1989b). Argument transfer vs. Predication. A speculative trip around the structure of IP in Basque. Ms. University of Connecticut.

Uribe-Etxebarria, Myriam. 1990. "Modal verbs in Basque", ms. UCONN. 